\title{
Origin of lipid biomarkers in mud volcanoes from the Alboran Sea, western Mediterranean
}

\author{
C. López-Rodríguez ${ }^{1}$, A. Stadnitskaia ${ }^{2}$, G. J. De Lange ${ }^{3}$, F. Martínez-Ruíz ${ }^{1}$, M. Comas ${ }^{1}$, and J. S. Sinninghe Damsté ${ }^{2,3}$ \\ ${ }^{1}$ Instituto Andaluz de Ciencias de la Tierra (CSIC-Granada University), Armilla, Spain \\ ${ }^{2}$ NIOZ Royal Netherland Institute for Sea Research, Department of Marine Organic Biogeochemistry, Texel, the Netherlands \\ ${ }^{3}$ Faculty of Geosciences, Utrecht University, Utrecht, the Netherlands \\ Correspondence to: C. López-Rodríguez (carmina@ugr.es)
}

Received: 28 October 2013 - Published in Biogeosciences Discuss.: 29 November 2013

Revised: 8 May 2014 - Accepted: 12 May 2014 - Published: 17 June 2014

\begin{abstract}
Mud volcanoes (MVs) are the most prominent indicators of active methane/hydrocarbon venting at the seafloor on both passive and active continental margins. Their occurrence in the western Mediterranean is patent at the West Alboran Basin, where numerous MVs develop overlaying a major sedimentary depocentre containing overpressured shales. Although some of these MVs have been studied, the detailed biogeochemistry of expelled mud so far has not been examined in detail. This work provides the first results on the composition and origin of organic matter, anaerobic oxidation of methane (AOM) processes and general characteristics on MV dynamics using lipid biomarkers as the main tool. Lipid biomarker analysis was performed on MV expelled material (mud breccias) and interbedded hemipelagic sediments from Perejil, Kalinin and Schneider's Heart MVs located in the northwest margin of the Alboran Sea. The $n$ alkane distributions and $n$ alkane-derived indices (CPI and ACL), in combination with the epimerization degree of hopanes $(22 \mathrm{~S} /(22 \mathrm{~S}+22 \mathrm{R}))$ indicate that all studied mud breccia have a similar biomarker composition consisting of mainly thermally immature organic matter with an admixture of petroleum-derived compounds. This concordant composition indicates that common source strata must feed all three studied MVs.

The past or present AOM activity was established using lipid biomarkers specific for anaerobic methanotrophic archaea (irregular isoprenoids and dialkyl glycerol diethers) and the depleted carbon isotope composition $\left(\delta^{13} \mathrm{C}\right)$ of crocetane/phytane. The presence of these lipid biomarkers, together with the low amounts of detected glycerol dialkyl glycerol tetraethers, is consistent with the dominance of
\end{abstract}

anaerobic methanotrophs of the ANME-2 over ANME-1, at least in mud breccia from Perejil MVs. In contrast, the scarce presence or lack of these AOM-related lipid biomarkers in sediments from Kalinin and Schneider's Heart MVs, suggests that no recent active methane seepage has occurred at these sites. Moreover, the observed methane concentrations support the current activity of Perejil MV, and the very low methane seepage activity in Kalinin and Schneider's Heart MVs.

\section{Introduction}

Mud volcanoes (MVs) are mainly formed due to an extensive discharge of hydrocarbon-rich fluids from deeper sedimentary units. This phenomenon, commonly occurring in petroliferous regions, results from upward transport of deepgenerated water and hydrocarbons to the subsurface (e.g. Guliyev and Feizullaev, 1997). The emitted fluids consist of a mixture of mud, water and gases, mainly methane, together with an admixture of carbon dioxide, hydrogen sulfide, heavier methane homologues and other petroleum components (Dimitrov, 2002; Milkov et al., 2003). The origin of hydrocarbon gases at MVs can be either thermogenic (formed by maturation of buried organic matter in the subsurface as a consequence of increasing temperature and pressure) or biogenic (produced by anaerobic microorganisms from organic matter at low temperatures), or a mixture of both (Milkov et al., 2003; Stadnitskaia et al., 2007, 2008; Mastalerz et al., 2007, 2009; Etiope et al., 2009). 


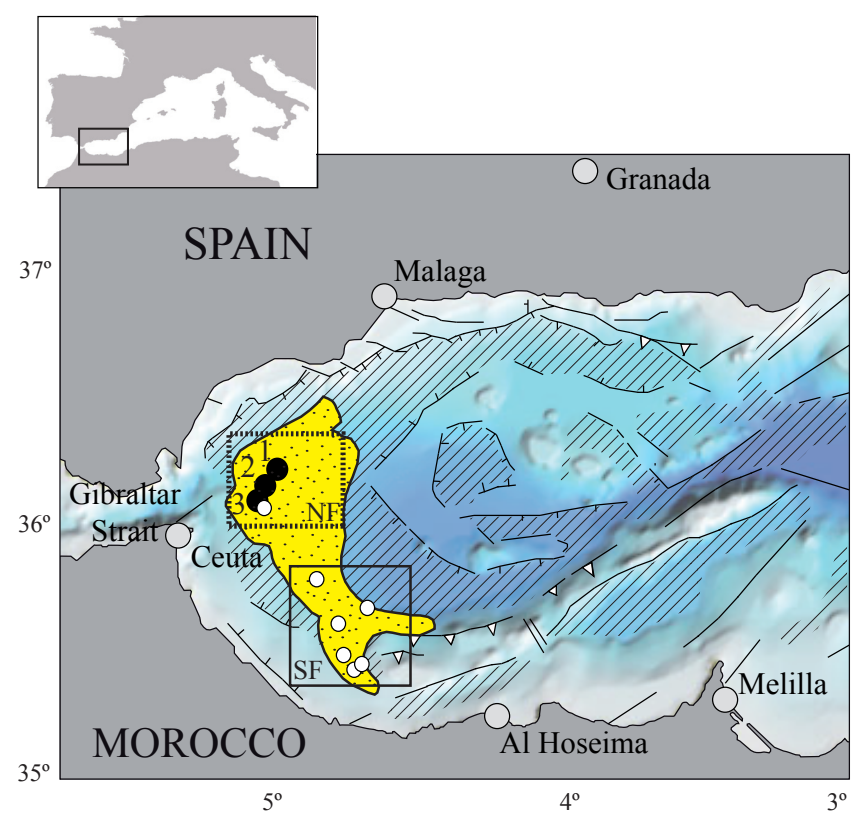

Figure 1. The Alboran Sea showing the location of the Mud Diapir Province and the Northern (NF) and Southern (SF) MV fields. Black dots correspond to the studied (1) Perejil, (2) Kalinin and (3) Schneider's Heart MVs; white dots refer to other MVs. Modified after Comas et al. (1999).

In addition to hydrocarbon-rich fluids, MVs expel large volumes of clastic volcanic material called "mud breccia" (Cita et al., 1981; Akhmanov, 1996). This is a complex mixture of matrix and rock fragments, mechanically incorporated into the eruption deposit by the powerful upward transport of fluids (Akhmanov, 1996; Akhmanov and Woodside, 1998). Mud breccias, rock clasts and matrix contain important information regarding the composition and genesis of sediments in the subsurface, their maturity and the hydrocarbon potential of the area (Akhmanov, 1996; Ovsyannikov et al., 2003; Wheeler and Stadnitskaia, 2011 and references therein).

Ascending fluids radically affect sedimentary environments at and below the sea floor. Due to the supply of organic and inorganic components (methane, hydrogen sulfide, carbon dioxide), MVs and cold seeps in general support a unique niche of microbes and other organisms, establishing their survival through chemosynthesis (e.g. Olu et al., 1996; Corselli and Basso, 1996; Vanreusel et al., 2009). Microbial anaerobic oxidation of methane (AOM) is performed by a consortium of anaerobic methane-oxidizing archaea (ANME) and sulfate-reducing bacteria (SRB) (Reeburgh 1976, 1996; Boetius et al., 2000, Knittel and Boetius, 2009) and is considered to be one of the main processes occurring at MVs and methane seepage environments. The methanotrophic archaea (falling in the ANME-1, -2 and -3 phylogenetic clusters; Knittel et al., 2005) that mediate this process contain a variety of ${ }^{13} \mathrm{C}$-depleted diagnostic lipid biomarkers such as glycerol dialkyl glycerol tetraethers (GDGTs), iso- prenoidal dialkyl glycerol diethers (DGDs) or irregular isoprenoids (Niemann and Elvert, 2008 and references therein). Thus, their presence in sediments provides information on the presence of AOM processes, and therefore the availability of methane.

Here we report the lipid biomarker composition of Alboran MVs, i.e. Perejil, Kalinin and Schneider's Heart (Fig. 1). We use these data to assess the source strata for the expelled materials and to determine the thermal maturity level of the organic matter present in the mud breccia matrices. We use lipid biomarkers related to methanotrophic archaea, and the measured methane content to evaluate the recent activity of these MVs. In addition, we apply the relative contribution of methanotrophic Euryarchaeota vs. planktonic Thaumarchaeota, to determine the AOM active zone. Furthermore, on the basis of lipid biomarker distribution and compoundspecific stable carbon isotope composition, we also discuss the AOM microbial community.

\section{Geological background}

The Alboran Sea is a marginal basin located in the westernmost Mediterranean Sea. Differences in structural architecture, sedimentary infill and seafloor morphology within make it possible to differentiate the western, eastern and southern Alboran Basins (Fig. 1). The Alboran Sea Basin is a remnant of the Miocene back-arc basin from the Gibraltar Arc System. The Gibraltar Arc System comprises the Betics (Spain) and Rif (Morocco) orogenic arc, the Alboran and Algerian back-arc basins, and the forearc accretionary prism in the Atlantic side. Within the Gibraltar Arc System, the Alboran Basin evolved since the Late Oligocene in a geodynamic setting characterized by a pervasive north-south convergence between the Eurasian and African plates (Dewey et al., 1989).

Geological and geophysical data demonstrate that the Alboran Sea originated in the Early Miocene, and evolved first by extensional tectonics (from Middle to Upper Miocene) and later has undergone significant contractive tectonics (from Late Miocene onwards). Post-Miocene contractive tectonics caused a major reorganization of the basin, which resulted in prominent north-south shortening of the marine realm and uplifting and emersions on the surrounding Betics and Riff chains. The recent and actual active tectonics conditioned the present coastal line position, as well as the current seafloor morphology (Comas et al., 1999; and references therein).

Basement and sedimentary cover beneath the Alboran Sea are known from commercial wells and ODP Leg 161 drilling. The thicker sedimentary depocentre is located in the West Alboran Basin (Fig. 1) where more than $7 \mathrm{~km}$ of sediments exist on top of the metamorphic basement (Fig. 2) (Jurado and Comas, 1992; Soto et al., 1996; Comas et al.,1996). 
Table 1. General sampling information on the studied sites: location, water depth and length of the studied cores.

\begin{tabular}{llllll}
\hline Core Code & Structure & Location & Sampling Site & Depth (m) & Recovery $(\mathrm{cm})$ \\
\hline RL07BC & Perejil Mud Volcano & $36^{\circ} 6.11^{\prime} \mathrm{N} ; 04^{\circ} 53.08^{\prime} \mathrm{W}$ & Flank & 818.9 & 40.0 \\
RL08GC & Perejil Mud Volcano & $36^{\circ} 6.11^{\prime} \mathrm{N} ; 04^{\circ} 53.08^{\prime} \mathrm{W}$ & Flank & 822.4 & 262.5 \\
RL30BC & Perejil Mud Volcano & $36^{\circ} 6.07^{\prime} \mathrm{N} ; 04^{\circ} 53.11^{\prime} \mathrm{W}$ & Crater & 807.8 & 30.0 \\
RL31GC & Perejil Mud Volcano & $36^{\circ} 6.07^{\prime} \mathrm{N} ; 04^{\circ} 53.11^{\prime} \mathrm{W}$ & Crater & 807.8 & 270.5 \\
RL12GC & Kalinin Mud Volcano & $36^{\circ} 3.00^{\prime} \mathrm{N} ; 04^{\circ} 55.90^{\prime} \mathrm{W}$ & Flank & 872.6 & 280.0 \\
RL25GC & Schneider's Heart Mud Volcano & $36^{\circ} 0.28^{\prime} \mathrm{N} ; 04^{\circ} 57.57^{\prime} \mathrm{W}$ & Flank & 924.0 & 310.0 \\
\hline
\end{tabular}

The West Alboran Basin is characterized by the presence of extensive shale (mud rocks) diapirism and shale tectonics conditioned by the existence of overpressured units at depth (Comas et al., 1999, 2012; Soto et al., 2010). Overpressure is conditioned by significant gas and fluids contents in the basal units of the West Alboran Basin (Unit VI and Unit V from Jurado and Comas, 1992; Fig. 2), as has been reported by logging (sonic velocity, density and resistivity) data from Andalucia-G1 and Alboran-A1 boreholes drilled in the West Alboran Basin. Furthermore, borehole sampling indicates that Unit VI (Burdigalian in age) is formed of undercompacted (pressurized) olistostromic or brecciated materials made of heterogeneous rock-fragments (blocks, boulders and clasts) of different ages embedded in a shale matrix intercalated with clayey, marly and sandy intervals, and that Unit $\mathrm{V}$ (Langhian in age) also contains under-compacted green clays (Jurado and Comas, 1992; Diaz-Merino et al., 2003) (Fig. 2).

Mud volcanism and pockmarks occurring in the West Alboran Basin lie on top of the huge Mud Diapir Province that extends from the Iberian to the Moroccan margins (Fig. 1). As evidenced by previous works, the mud volcanism is linked to recent stages of shale diapirism happened during compressive tectonics (Plio-Quaternary, from 4-5 Ma onwards), which conditioned pierced diapirs and lend subsequently to mud volcanism at the seafloor (Comas et al., 2010; and references therein). Seismic profiles show that volcano feeder-channels connect to deeper shale-diapir structures proving that volcanic processes bring up to the seafloor over-pressured shales and olistostromes from Unit VI (Fig. 2) laying at more than $5 \mathrm{~km}$ deep (Talukder et al., 2003; Comas et al., 2012).

The extruded mud breccias contain exotic rocks from different sedimentary units. Micropalaeontological data from core sampling indicate that MVs bring up to the seafloor sedimentary rocks of different ages but ranging from the Late Cretaceous to the Late Miocene (Sautkin et al., 2003; Gennari et al., 2013). A deep thermogenic source of fluids expelled by the Alboran MVs has been suggested on the basis of ${ }^{13} \mathrm{C}$ isotope determinations in authigenic carbonates, pore-water analyses and gas composition (Blinova et al., 2011; López-Rodríguez et al., 2014). Abundance of chemosynthetic habitats (bivalves, tube worms) on the top of some MVs concludes current methane/hydrocarbon seeping in some of them (Hilário et al., 2011). However, the majority of the Alboran MVs seem to be inactive, or maybe just dormant (Comas et al., 2010).

\section{Materials and methods}

\subsection{Samples}

The studied sediment cores were collected during the first leg of Ristretto e Lungo expedition in December 2010 on board $\mathrm{R} / \mathrm{V}$ Meteor. In total, sediments from four gravity cores and two box-cores (Fig. 2, Table 1) were chosen for this study on the basis of changes in lithology, gas manifestation and gas saturation. The sampling operations were performed using a $1200 \mathrm{~kg}$ gravity corer with a $6 \mathrm{~m}$ barrel and $11 \mathrm{~cm}$ inner diameter tubings. The $900 \mathrm{~kg}$ box-corer had a round box with an internal diameter of $30 \mathrm{~cm}$ and a height of $55 \mathrm{~cm}$. The recovered gravity cores were cut in $1 \mathrm{~m}$ sections, split open lengthwise and lithologically described. Box-cores were subsampled using pvc tubes of $50 \mathrm{~cm}$ length and $9 \mathrm{~cm}$ inner diameter which were pushed vertically in the sediment. Subsequently, these sampling tubes were split open lengthwise and lithologically described. The sub-sampling for lipid biomarkers was done on board in a $+4{ }^{\circ} \mathrm{C}$ container as soon as possible after recovery. The sediment was sampled every $2-$ $5 \mathrm{~cm}$ taking into consideration lithological variations. Samples were stored and transported at $-20^{\circ} \mathrm{C}$ for on-land laboratory studies.

\subsection{Extraction and separation}

A total of $20-50 \mathrm{~g}$ of freeze-dried sediments were crushed to a fine powder, and extracted with an automatic Accelerated Solvent Extractor (ASE 200/DIONEX) using a solvent mixture of dichloromethane: methanol $(9: 14, v / v)$ at $1000 \mathrm{psi}$ and $100{ }^{\circ} \mathrm{C}$. The obtained total lipid extracts were rotary evaporated to near dryness and elemental sulfur was removed by adding ca. $10 \mathrm{mg}$ of activated copper and stirring the sample overnight. An aliquot of the total lipid extract was used for analysis of total lipid distribution. To this end, fatty acids were methylated by adding $\mathrm{CH}_{2} \mathrm{~N}_{2}$ and alcohol groups were silylated by adding $25 \mu \mathrm{L}$ pyridine and $25 \mu \mathrm{L}$ 

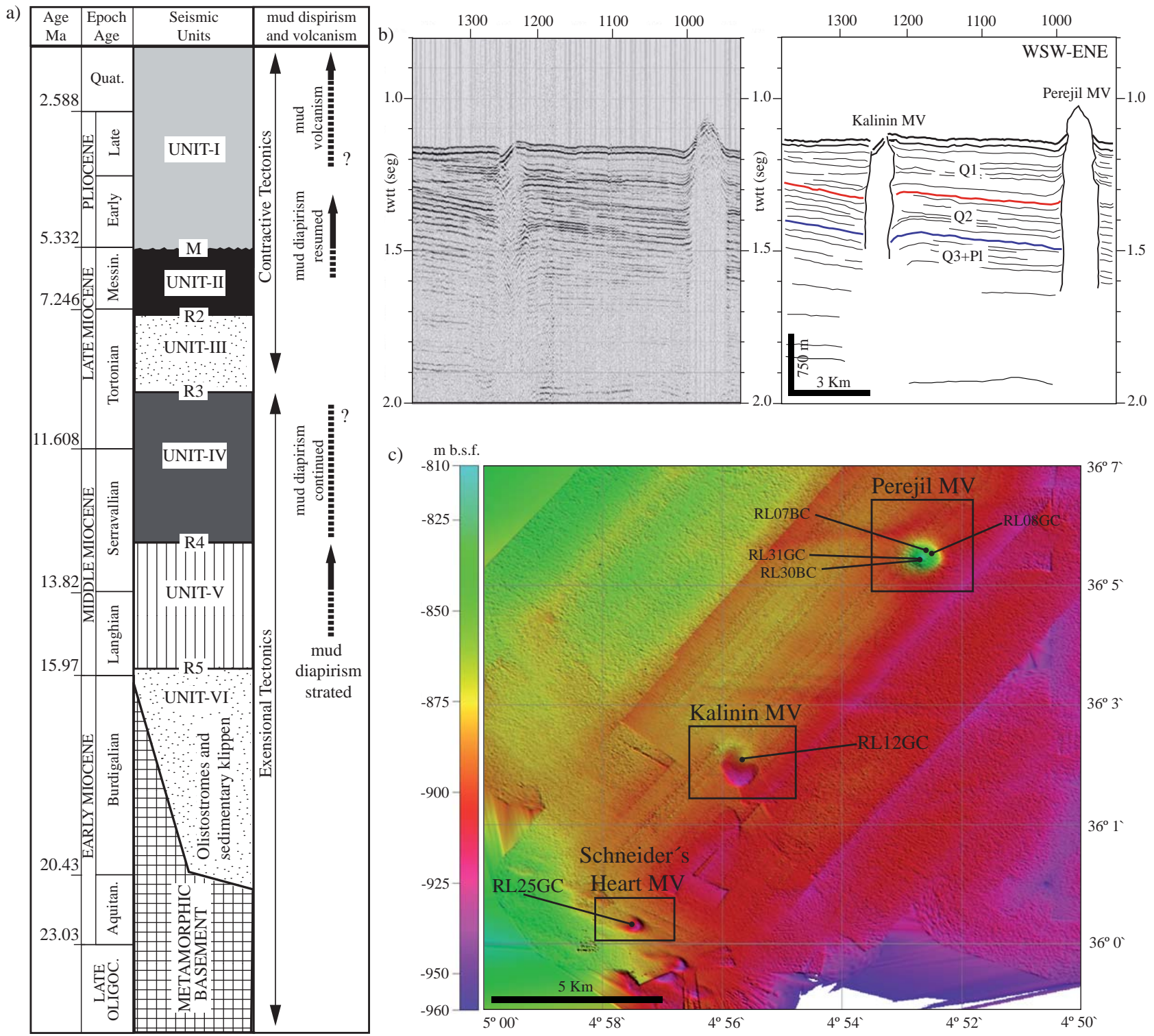

Figure 2. (a) Seismic stratigraphic units, major regional reflectors and main sedimentary sequence documented in the Betic Neogene basins (modified after Jurado and Comas, 1992; Rodríguez-Fernández et al., 1999); M: Messinian unconformity. R: reflectors correspond to major unconformities within sediments. (b) High-resolution seismic line PS200MS across Perejil and Kalinin MVs (Talukder, 2003); Blue and red lines refer to seismic reflectors within the Plio-Quaternary sequence (Unit I) (Jurado and Comas, 1992; Comas et al., 1999). (c) Multibeam swath bathymetry of the Northern MV field showing Perejil, Kalinin and Schneider's Heart MVs. Numbers referred to studied sites (gravity and box-cores).

of $N, O$-bis(trimethylsilyl)-trifluoroacetamid (BSTFA) and heating at $60{ }^{\circ} \mathrm{C}$ for $20 \mathrm{~min}$. Another part of the total lipid extract was chromatographically separated into apolar and polar fractions using a column with $\mathrm{Al}_{2} \mathrm{O}_{3}$ (activated for $2 \mathrm{~h}$ at $150{ }^{\circ} \mathrm{C}$ ) as stationary phase. Apolar compounds were eluted using hexane: dichloromethane $(9: 1, v / v)$, and polar compounds, including glycerol diethers and glycerol dialkyl glycerol tetraethers (GDGTs) core membrane lipids, were obtained with methanol: dichloromethane $(1: 1, v / v)$ as eluent. To calculate absolute concentration of biomark- ers in mud breccia matrices, a known amount of anteiso- $\mathrm{C}_{22}$ hydrocarbon was added to each fraction as internal standard (Stadnitskaia et al., 2007, 2008).

\subsection{Analysis and identification of lipid biomarkers}

Gas chromatography (GC) was performed with a Thermo Finnigan TRACE instrument equipped with a fused silica capillary column (CP Sil-5, $25 \mathrm{~m} \times 0.32 \mathrm{~mm}, d_{\mathrm{f}}=0.12 \mu \mathrm{m}$ ), with a flame ionization detector and helium as a carrier gas. 
Samples were injected at $70^{\circ} \mathrm{C}$. The $\mathrm{GC}$ oven temperature was subsequently raised to $130^{\circ} \mathrm{C}$ at a rate of $20^{\circ} \mathrm{C} \mathrm{min}-1$, and then to $320^{\circ} \mathrm{C}$ at $4^{\circ} \mathrm{C} \mathrm{min}^{-1}$. The temperature was then held constant for $15 \mathrm{~min}$.

All fractions were analysed by gas chromatography-mass spectrometry (GC-MS) for compound identification. The gas chromatograph was coupled to a Thermo Finnigan TRACE DSQ quadrupole mass spectrometer with ionization energy of $70 \mathrm{eV}$, with a mass range of $m / z$ 50-800. GC conditions of GC-MS were the same as those described for GC.

To determine the distribution of intact glycerol dialkyl glycerol tetraethers (GDGTs), the polar fractions of the sediment extracts were analysed using high-performance liquid chromatography-mass spectrometry (HPLC-MS) (Hopmans et al., 2000) using an Agilent 1100 series/1100 MSD series instrument, with auto-injection system and HP Chemstation software. An Alltech Prevail Cyano column $(150 \mathrm{~mm} \times 2.1 \mathrm{~mm}, 3 \mu \mathrm{m})$ was used with hexane: propanol (99: $1,13 \mathrm{v})$ as mobile phase $\left(0.2 \mathrm{~mL} \mathrm{~min}^{-1}\right)$. After $5 \mathrm{~min}$, a linear gradient to $1.8 \%$ propanol was used (45 min). MS analysis and quantification of both isoprenoidal and branched GDGTs followed methods reported by Weijers et al. (2006). The GDGT-based ratios (Methane Index, MI; GDGT-0/Crenarchaeol and GDGT-2/Crenarchaeol) were applied to express the relative distribution of methanotrophic Euryarchaeota (presumably represented by GDGT-1, -2 and 3 ) vs. planktonic and possibly benthic Thaumarchaeota (represented by crenarchaeol and its regioisomer) (Sinninghe Damsté et al., 2002; Zhang et al., 2011; Weijers et al., 2011; Schouten et al., 2012).

Isotope-ratio-monitoring GC-MS (IRM-GC-MS) was performed on a Finnigan MAT Delta Plus XL instrument used for determining compound-specific $\delta^{13} \mathrm{C}$ values. The GC used was a Hewlett Packard 6890 A series, and the same analytical conditions were used as described for GC and GCMS. For carbon isotopic correction of the added trimethylsilyl groups, the stable carbon isotope composition of the used BSTFA was determined. Obtained values were reported in per mil relative to the VPDB standard. In order to monitor the accuracy of the measurements, the analyses were carried out with co-injection of two standards, $\mathrm{C}_{20}$ and $\mathrm{C}_{24} n$ alkanes, with a known stable carbon isotope composition.

\subsection{Methane and sulfate analyses}

Methane concentrations in hemipelagic sediments and mud breccia from Perejil, Kalinin and Schneider's Heart MVs were routinely measured on board. Decapped $10 \mathrm{~mL}$ syringes were used to sample the fresh sediment immediately upon recovery. The volume of sediment was rapidly put into a $65 \mathrm{~mL}$ glass vial prefilled with a saturated $\mathrm{NaCl}$ solution. The vial was immediately closed and mixed. Subsequently, a $5 \mathrm{~mL}$ headspace was made (for full procedure, see Mastalerz et al., 2007).
The methane concentration in the headspace was determined on-board with a Shimadzu gas chromatograph with a flame ionization detector.

For sulfate analyses, the pore water was extracted on board using rhizons, acidified, and analysed on land using ICP-AES (for details see Mastalerz et al., 2007).

\section{Results}

\subsection{Core lithologies}

\subsubsection{Perejil MV}

Two gravity cores and two box-cores were taken at Perejil MV. Cores RL08GC and RL07BC were taken from the flank, RL31GC and RL30BC from the crater of the structure (Fig. 2). The "flank" box-core RL07BC contained $40 \mathrm{~cm}$ of typical structureless dark grey mud breccia, for which the top $10 \mathrm{~cm}$ were oxidized (Fig. 3a). At this site, methane bubbles were present as well as abundant Pogonophora tube worms at the top. Additionally, chemosynthetic fauna such as living Acharax bivalves were found at $\sim 10 \mathrm{~cm}$ depth in the mud breccia. Core RL08GC, also taken at the flank, contained $263 \mathrm{~cm}$ of alternations of hemipelagic sediments and mud breccia (Fig. 3a). Although two mud breccia layers could be distinguished, the boundaries were not always fully distinct. The upper layer, from $65-79 \mathrm{~cm}$, consisted of soft mousselike mud breccia with occasional rock clasts, intensively bioturbated. The lower interval from $135-209 \mathrm{~cm}$ consisted of stiff mud breccia moderately bioturbated in the uppermost part. In both mud breccia intervals a few fragments of mudstone were found, and there was a distinct, moderate smell of $\mathrm{H}_{2} \mathrm{~S}$. Hemipelagic sediments consisted of greyish brown marls with some foraminifera. The two sedimentary locations within the crater of Perejil MV showed different lithologies at their topmost sediments (hemipelagic and mud breccia, respectively) (Fig. 3a).

In contrast to the sediments on the flank of the MV, the $271 \mathrm{~cm}$ of crater sediments in core RL31GC were composed of a typical structureless dark grey mud breccia, with millimetre- to centimetre-sized rock clasts of claystone, mudstone and carbonates (Fig. 3a). At this site, no hemipelagic cover was present and a strong scent of $\mathrm{H}_{2} \mathrm{~S}$ was noticed along the whole mud breccia section. The top $8 \mathrm{~cm}$ were visibly bioturbated. This is consistent with observations in the nearby box-core RL30BC that contained $30 \mathrm{~cm}$ of oxidized mud breccia for which the top $10 \mathrm{~cm}$ were clearly bioturbated. Authigenic pyrite in the form of spherules of centimetric size and concretions were observed in the mud breccia matrix and rock clasts from this site.

\subsubsection{Kalinin and Schneider's Heart MVs}

Gravity cores taken from Kalinin and Schneider's Heart MVs (RL12GC and RL25GC; Fig. 2) recovered 272 and 

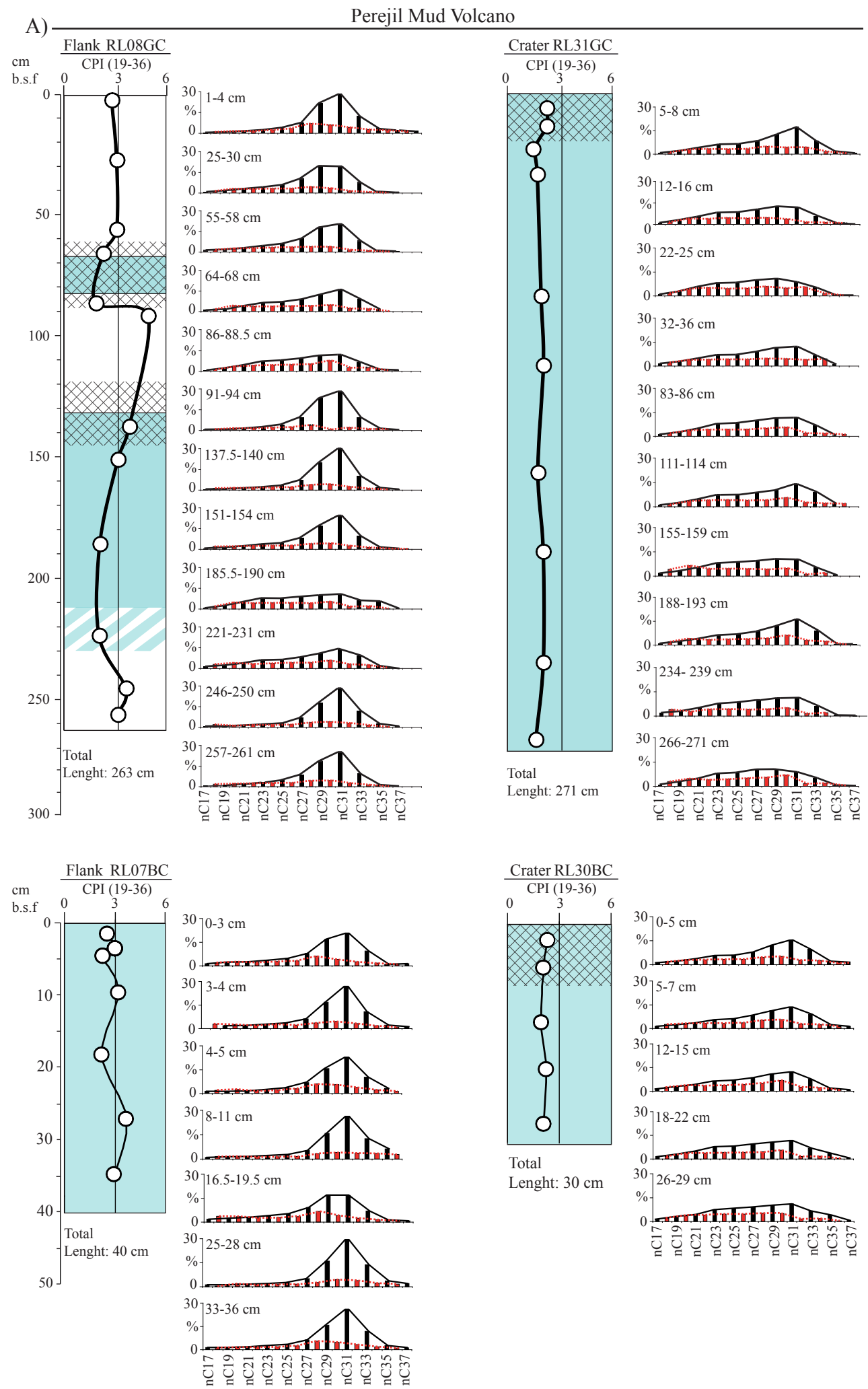

Figure 3. Distribution of $n$ alkanes and carbon preference index (CPI) profiles along the sedimentary sections for (A) Perejil MV flank and crater and (B) Kalinin and Schneider's Heart MVs. Striped area corresponds to hemipelagic sediments with lipid characteristics of mud breccia. Relative concentrations were calculated by normalization of peak areas obtained by gas chromatography. 

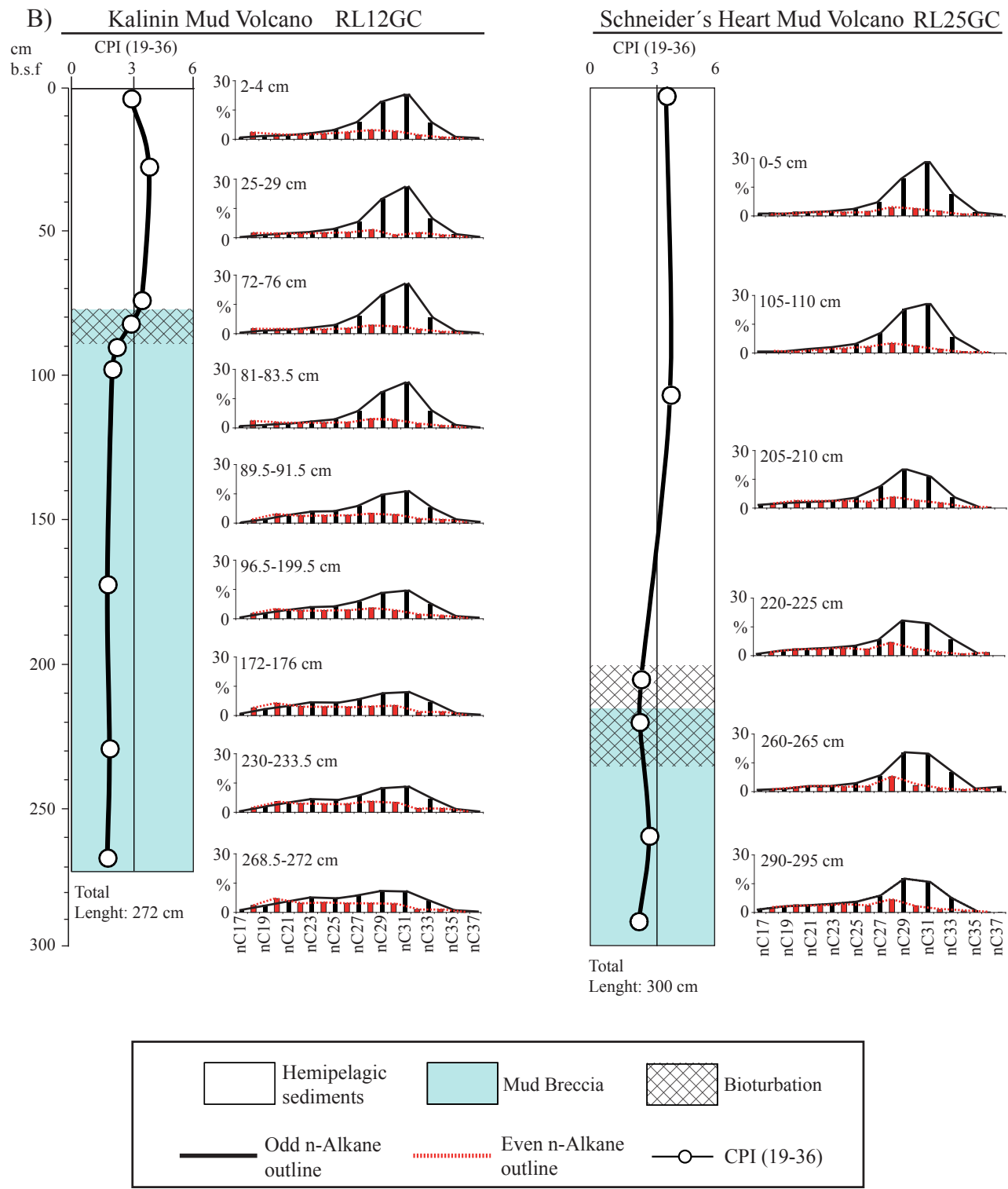

Figure 3. Continued.

$300 \mathrm{~cm}$, respectively, containing both hemipelagic sediments and mud breccia. The lowermost part of the hemipelagic sediments at Schneider's Heart MVs was moderately bioturbated (Fig. 3b), and at this site and at Kalinin MV the boundary with the mud breccia interval were irregular and not well expressed. In both structures the mud breccia intervals were covered with hemipelagic sediments: 78 and $217 \mathrm{~cm}$ at Kalinin and Schneider's Heart MVs, respectively. MV deposits in both locations were represented by mousselike mud breccia with a few millimetre-sized rock clasts of sandstone and mudstone. At both MVs, the upper part of the mud breccia interval was moderately bioturbated.

\subsection{Lipid biomarker distributions}

The total lipid fractions of different sediment horizons from the MVs sedimentary cores showed similar lipid biomarker distribution patterns; apolar compounds significantly dominated over the polar. Hydrocarbons (within the analytical window of gas chromatography; i.e. up to a molecular weight of ca. $800 \mathrm{Da}$ ) were mainly represented by a series of $\mathrm{C}_{17}$ $\mathrm{C}_{37} n$ alkanes with dominance of $n \mathrm{C}_{23}-n \mathrm{C}_{33}$, with a maximum at $n \mathrm{C}_{29}$ or $n \mathrm{C}_{31}$, and a moderate odd-over-even carbon number predominance (Fig. 3). The carbon preference index $(\mathrm{CPI})_{(19-36)}$ (Bray and Evans, 1961) as well as the average chain length (ACL) (Poynter, 1989) indices showed some variation along the sedimentary sections, mainly at the 


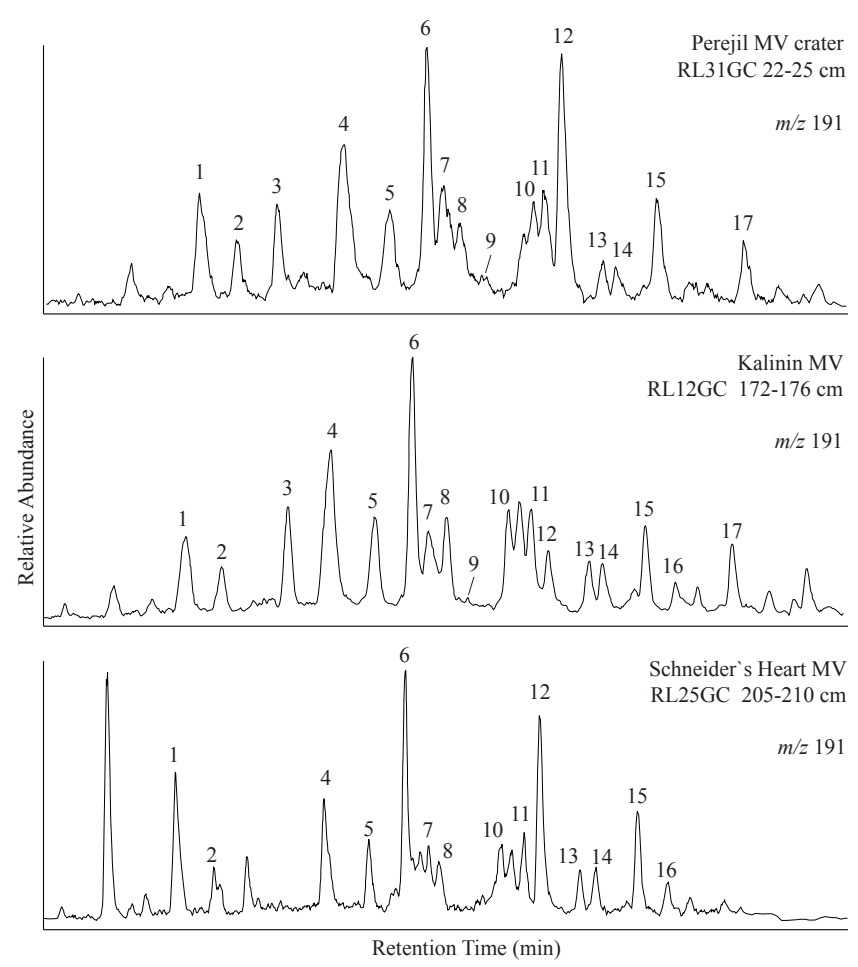

Figure 4. Typical $\mathrm{m} / \mathrm{z} 191$ mass chromatograms showing distributions of pentacyclic triterpenoids present in selected mud breccia samples of Perejil, Kalinin and Schneider's Heart MVs. Numbers refer to compounds listed in Table 3.

boundary between hemipelagic sediments and mud breccia intervals. In mud breccia intervals the CPI values varied between 2.0 and 2.9 and ACL values ranged from 27.4 to 29.4 (Fig. 3, Table 2). Compared to mud breccia, hemipelagic sediments showed higher $\mathrm{CPI}_{(19-36)}$ values, from 3.0-3.4, as well as higher ACL values, from 28.8-29.1 (Fig. 3, Table 2). As noted above, the boundaries between hemipelagic sediments and mud breccia were not always distinct. This seems also apparent for the CPI index, most notably for the lowermost mud interval at Perejil flank (RL08GC, Fig. 3a).

Pentacyclic triterpanes were identified at all studied MVs (Fig. 4, Table 3). For the apolar fractions the $17 \alpha, 21 \beta(\mathrm{H})-$ hopane $\left(\mathrm{C}_{30}\right)$ was the most dominant compound followed by $22 R 17 \alpha, 21 \beta(\mathrm{H})$-homohopane $\left(\mathrm{C}_{31}\right)$ and $17 \alpha, 21 \beta(\mathrm{H})$ 30-norhopane (Fig. 4, Table 3). Hopanes with the $17 \alpha, 21 \beta$ $(\mathrm{H})$-configuration in the range of $\mathrm{C}_{30}-\mathrm{C}_{32}$ were the main epimers. In this range, $\beta \alpha$-epimeric series were not detected and the only hopane with $17 \beta, 21 \beta(\mathrm{H})$-configuration found was homohopane. Unsaturated hopanoids were represented by neohop-13(18)-ene, and hop-22(29)-ene (diploptene; V see Supplement for structures) (Fig. 4, Tables 3-4). $\mathrm{C}_{32}$ benzohopane was only found in the mud breccia of Perejil and Kalinin MVs (Fig. 4, Table 3). Functionalized triterpenoids were represented by diplopterol $(17 \beta, 21 \beta(\mathrm{H})$-hopan-22-ol;

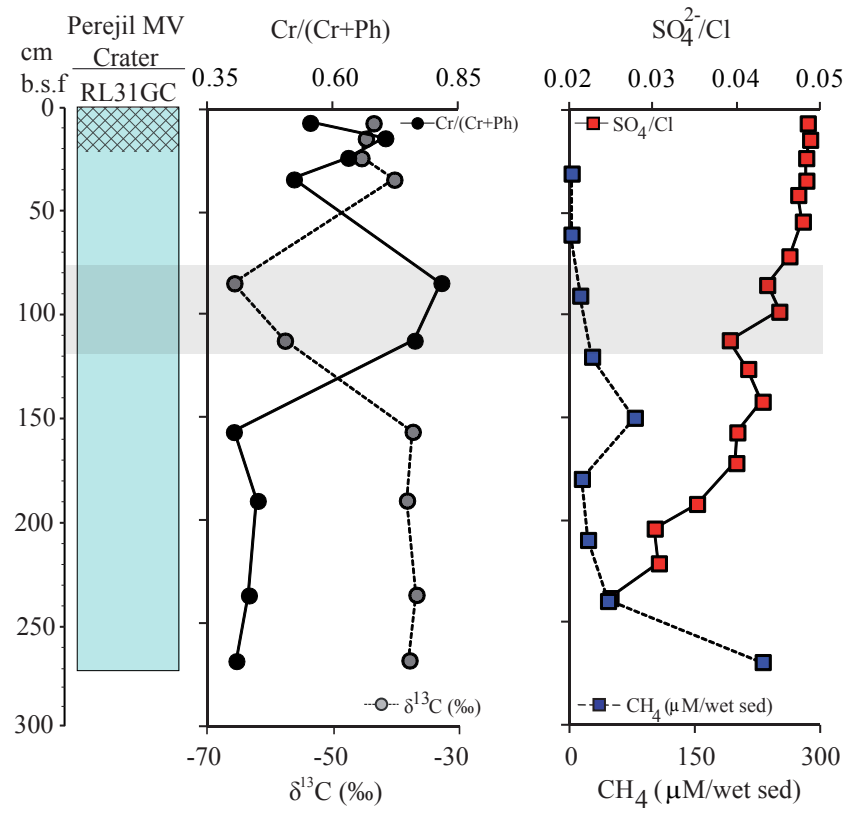

Figure 5. Fractional abundance of crocetane $(\mathrm{Cr} /(\mathrm{Cr}+\mathrm{Ph}))$ and the stable carbon isotope composition of the phytane/crocetane peak vs. depth in mud breccia of the Perejil MV crater. Concentrations of methane and $\mathrm{SO}_{4}^{2-} / \mathrm{Cl}$ ratio from gases and pore fluids showing the zone of anaerobic oxidation of methane (AOM).

VI), which was detected only in Perejil and Kalinin MVs (Fig. 4, Tables 3-4).

Irregular isoprenoids diagnostic for methanotrophic archaea associated with AOM (e.g. Elvert et al., 2000; Pancost et al., 2000; Hinrichs et al., 2000) such as crocetane (2, 6, 11, 15-tetramethylhexadecane; I) and PMI (2, 6, 10, 15, 19-pentamethylicosane; II), were identified at all studied sites (Table 4). Crocetane was present in all the studied sites, whereas PMI was found only at few depths intervals at Perejil, Kalinin and Schneider's Heart MVs (Table 4). Sediments from the crater of Perejil MV were examined for the presence of crocetane relative to the more common and coeluting acyclic isoprenoid phytane. This was done using the examination of mass chromatograms for $\mathrm{m} / \mathrm{z} 183$ and $\mathrm{m} / \mathrm{z}$ 169 - diagnostic fragment ions for phytane and crocetane, respectively (see Bian et al., 2001). This resulted in an estimated fractional abundance of crocetane of 0.4 to 0.8 at $80-110 \mathrm{~cm}$ (Fig. 5). Compound-specific stable carbon isotope measurements of the peak comprised of crocetane and phytane revealed a variation from -65 to $-37 \%$, with the lowest values in the $80-110 \mathrm{~cm}$ interval (Fig. 5).

Archaea-derived isoprenoid dialkyl glycerol diethers (DGDs), such as archaeol (III) and hydroxyarchaeol (IV), were found at two MVs. Archaeol was detected in the mud breccia from Perejil, both at the crater and flank sites, and Kalinin MVs. Hydroxyarchaeol was only identified in the mud breccia from Perejil MV crater as well as in 
Table 2. Compound indices related with $n$ alkanes (CPI and ACL), hopane and GDGTs-based ratios for the studied sites.

\begin{tabular}{|c|c|c|c|c|c|c|c|c|c|}
\hline Lithology & intervals (cm b.s.f.) & $\begin{array}{l}n \text {-Alkanes } \\
\text { CPI } \\
(\mathrm{C} 19-\mathrm{C} 36)\end{array}$ & $\begin{array}{l}\text { CPI } \\
\text { (C29-C32) }\end{array}$ & $\begin{array}{l}\text { ACL } \\
\text { (C19-C35) }\end{array}$ & $\begin{array}{l}\text { Hopanoids } \\
\text { C31 } \\
22 \mathrm{~S} /(22 \mathrm{~S}+22 \mathrm{R})\end{array}$ & $\begin{array}{l}\mathrm{C} 32 \\
22 \mathrm{~S} /(22 \mathrm{~S}+22 \mathrm{R})\end{array}$ & $\begin{array}{l}\text { GDGTs } \\
\text { Methane Index }\end{array}$ & $\begin{array}{l}\text { GDGT-2/ } \\
\text { Crenarch. }\end{array}$ & $\begin{array}{l}\text { GDGT-0/ } \\
\text { Crenarch. }\end{array}$ \\
\hline \multicolumn{10}{|c|}{ Perejil Mud Volcano Flank RL07BC } \\
\hline \multirow[t]{7}{*}{ Mud Breccia } & $0-3$ & 2.6 & 4.6 & 28.8 & - & - & 0.22 & 0.14 & 0.61 \\
\hline & $3-4$ & 3.0 & 5.5 & 29.4 & - & - & 0.20 & 0.13 & 0.56 \\
\hline & $4-5$ & 2.3 & 3.7 & 29.5 & - & - & 0.20 & 0.12 & 0.56 \\
\hline & $8-11$ & 3.2 & 5.6 & 30.1 & - & - & 0.23 & 0.15 & 0.68 \\
\hline & $16.5-19.5$ & 2.3 & 4.1 & 28.4 & - & - & 0.21 & 0.13 & 0.60 \\
\hline & $25-28.5$ & 3.7 & 5.9 & 30.0 & - & - & 0.21 & 0.13 & 0.58 \\
\hline & $33-36$ & 3.0 & 4.7 & 29.6 & - & - & 0.20 & 0.12 & 0.56 \\
\hline Hem. Sed. Average & & - & - & - & - & - & - & - & - \\
\hline M.B. Average & & 2.9 & 2.9 & 29.4 & - & - & 0.21 & 0.13 & 0.59 \\
\hline Main Average & & 2.9 & 2.9 & 29.4 & - & - & 0.21 & 0.13 & 0.59 \\
\hline \multicolumn{10}{|c|}{ Perejil Mud Volcano Flank RL08GC } \\
\hline \multirow[t]{3}{*}{ Hemipelagic Sediments } & $1-4$ & 2.7 & 4.4 & 29.7 & - & - & 0.20 & 0.12 & 0.59 \\
\hline & $25-30$ & 3.0 & 6.4 & 28.5 & - & 0.53 & 0.21 & 0.13 & 0.60 \\
\hline & $55-58$ & 3.0 & 5.8 & 28.5 & 0.51 & 0.39 & 0.20 & 0.13 & 0.55 \\
\hline Mud Breccia & $64-68$ & 2.2 & 3.6 & 28.1 & 0.31 & 0.57 & 0.21 & 0.13 & 0.58 \\
\hline \multirow[t]{2}{*}{ Hem. Sed. } & $86-88.5$ & 1.7 & 2.1 & 27.5 & 0.38 & 0.36 & 0.25 & 0.17 & 0.61 \\
\hline & $91-94$ & 5.0 & 14.7 & 29.4 & 0.43 & 0.31 & 0.22 & 0.14 & 0.60 \\
\hline \multirow[t]{3}{*}{ Mud Breccia } & $137.5-140$ & 3.8 & 6.7 & 29.6 & 0.57 & 0.45 & 0.20 & 0.13 & 0.53 \\
\hline & $151-154$ & 3.1 & 5.5 & 29.1 & - & 0.41 & 0.23 & 0.15 & 0.56 \\
\hline & $185.5-190$ & 1.2 & 2.5 & 27.8 & 0.45 & 0.50 & 0.34 & 0.27 & 1.00 \\
\hline \multirow[t]{3}{*}{ Hemipelagic Sediments } & $221-231$ & 2.0 & 2.7 & 28.1 & 0.40 & - & 0.38 & 0.33 & 1.08 \\
\hline & $246-250$ & 3.6 & 6.1 & 29.8 & 0.38 & 0.31 & 0.21 & 0.13 & 0.56 \\
\hline & $257-261$ & 3.1 & 5.6 & 29.2 & 0.56 & 0.38 & 0.21 & 0.13 & 0.58 \\
\hline Hem. Sed. Average & & 3.0 & 3.1 & 28.8 & 0.44 & 0.38 & 0.31 & 0.21 & 0.86 \\
\hline M.B. Average & & 2.8 & 2.9 & 28.7 & 0.44 & 0.48 & 0.24 & 0.17 & 0.67 \\
\hline Main Average & & 3.0 & 3.1 & 28.8 & 0.44 & 0.42 & 0.29 & 0.20 & 0.78 \\
\hline Perejil Mud Volcano Cra & er RL30BC & & & & & & & & \\
\hline Mud Breccia & $0-5$ & 2.3 & 3.2 & 28.3 & - & - & 0.22 & 0.14 & 0.59 \\
\hline & $5-7$ & 2.1 & 2.6 & 28.2 & - & - & 0.19 & 0.12 & 0.54 \\
\hline & $12-15$ & 1.9 & 2.2 & 27.7 & - & - & 0.25 & 0.17 & 0.72 \\
\hline & $18-22$ & 2.2 & 2.6 & 27.5 & - & - & 0.26 & 0.18 & 0.75 \\
\hline & $26-29$ & 2.1 & 2.7 & 27.6 & - & - & 0.31 & 0.24 & 0.86 \\
\hline Hem. Sed. Average & & - & - & - & - & - & - & - & - \\
\hline M.B. Average & & 2.1 & 2.1 & 27.9 & - & - & 0.25 & 0.17 & 0.69 \\
\hline Main Average & & 2.1 & 2.1 & 27.9 & - & - & 0.25 & 0.17 & 0.69 \\
\hline Perejil Mud Volcano Cra & er RL31GC & & & & & & & & \\
\hline Mud Breccia & $5-8$ & 2.3 & 3.3 & 28.2 & - & 0.46 & 0.23 & 0.15 & 0.61 \\
\hline & $12-16$ & 2.3 & 3.9 & 27.2 & 0.38 & - & 0.21 & 0.13 & 0.62 \\
\hline & $22-25$ & 1.6 & 1.8 & 26.8 & 0.30 & 0.55 & 0.21 & 0.13 & 0.59 \\
\hline & $32-36$ & 1.7 & 2.6 & 27.4 & 0.50 & 0.47 & 0.22 & 0.13 & 0.61 \\
\hline & $83-86$ & 2.0 & 2.6 & 27.2 & 0.41 & 0.52 & 0.30 & 0.22 & 0.79 \\
\hline & $111-114$ & 2.1 & 2.8 & 27.8 & - & - & 0.29 & 0.22 & 0.84 \\
\hline & $155-159$ & 1.8 & 2.9 & 26.9 & - & - & 0.38 & 0.33 & 1.02 \\
\hline & $188-193$ & 2.1 & 2.9 & 28.0 & 0.46 & 0.52 & 0.33 & 0.26 & 0.94 \\
\hline & $234-239$ & 2.1 & 2.9 & 27.1 & 0.60 & & 0.33 & 0.26 & 0.97 \\
\hline & $266-271$ & 1.7 & 1.7 & 26.9 & 0.35 & 0.51 & 0.45 & 0.48 & 1.28 \\
\hline Hem. Sed. Average & & & & & & & & & \\
\hline M.B. Average & & 2.0 & 2.0 & 27.4 & 0.43 & 0.50 & 0.49 & 0.38 & 1.38 \\
\hline Main Average & & 2.0 & 2.0 & 27.4 & 0.43 & 0.50 & 0.49 & 0.38 & 1.38 \\
\hline Kalinin Mud Volcano RL & $12 \mathrm{GC}$ & & & & & & & & \\
\hline Hemipelagic Sediments & $2-4$ & 2.9 & 5.8 & 29.0 & 0.52 & 0.50 & 0.21 & 0.12 & 0.54 \\
\hline & $25-29$ & 3.8 & 10.0 & 29.3 & 0.39 & - & 0.22 & 0.12 & 0.55 \\
\hline & $72-76$ & 3.4 & 6.7 & 29.1 & 0.43 & 0.42 & 0.23 & 0.13 & 0.56 \\
\hline Mud Breccia & $81-83.5$ & 2.9 & 5.6 & 29.0 & 0.32 & 0.43 & 0.23 & 0.13 & 0.54 \\
\hline & $89.5-91.5$ & 2.2 & 4.1 & 28.2 & 0.45 & 0.53 & 0.26 & 0.15 & 0.66 \\
\hline & $96.5-100.5$ & 2.0 & 3.6 & 27.8 & 0.44 & 0.43 & 0.28 & 0.16 & 0.72 \\
\hline & $172-176$ & 1.7 & 2.9 & 27.5 & 0.55 & 0.47 & 0.35 & 0.22 & 0.86 \\
\hline & $230-233.5$ & 1.8 & 3.0 & 27.6 & 0.44 & 0.49 & 0.31 & 0.19 & 0.74 \\
\hline & $268.5-272$ & 1.7 & 3.0 & 27.1 & 0.42 & 0.45 & 0.35 & 0.22 & 0.85 \\
\hline Hem. Sed. Average & & 3.4 & 3.5 & 29.1 & 0.44 & 0.46 & 0.33 & 0.19 & 0.82 \\
\hline M.B. Average & & 2.1 & 2.1 & 27.9 & 0.43 & 0.47 & 0.30 & 0.18 & 0.73 \\
\hline Main Average & & 2.5 & 2.5 & 28.3 & 0.44 & 0.47 & 0.31 & 0.18 & 0.75 \\
\hline Schneider's Heart Mud V & lcano RL25GC & & & & & & & & \\
\hline Hemipelagic Sediments & $0-5$ & 3.7 & 6.7 & 29.6 & 0.43 & 0.57 & 0.19 & 0.11 & 0.55 \\
\hline & $105-110$ & 3.9 & 7.1 & 29.2 & 0.35 & 0.42 & 0.26 & 0.17 & 0.69 \\
\hline & $205-210$ & 2.4 & 4.5 & 28.2 & 0.44 & 0.48 & 0.19 & 0.10 & 0.66 \\
\hline Mud Breccia & $220-225$ & 2.4 & 5.0 & 28.4 & 0.48 & 0.49 & 0.12 & 0.04 & 1.01 \\
\hline & $260-265$ & 2.8 & 5.9 & 29.1 & 0.57 & 0.50 & 0.10 & 0.03 & 1.02 \\
\hline & $290-295$ & 2.3 & 5.0 & 28.1 & 0.61 & 0.54 & 0.12 & 0.04 & 1.00 \\
\hline Hem. Sed. Average & & 3.3 & 3.4 & 29.0 & 0.41 & 0.49 & 0.22 & 0.13 & 0.63 \\
\hline M.B. Average & & 2.5 & 2.6 & 28.5 & 0.55 & 0.51 & 0.11 & 0.04 & 1.01 \\
\hline Main Average & & 3.0 & 3.1 & 28.7 & 0.48 & 0.50 & 0.16 & 0.08 & 0.82 \\
\hline
\end{tabular}


the uppermost sediments at the flank site (Table 4). Nonisoprenoidal DGDs (Pancost et al., 2001) were only identified at the mud breccia interval from Schneider's Heart MV (Table 4).

Specific glycerol dibiphytanyl glycerol tetraethers (GDGTs; Supplement) (Schouten et al., 2012 and reference therein) were detected in all cores. The GDGT distributions showed a clear dominance of isoprenoidal over branched GDGTs (Fig. 6). The isoprenoidal GDGTs were dominated by GDGT-0 (VII) and crenarchaeol (XI), with maximum abundances in average of 46 and $51 \%$, respectively, in mud breccias and 35 and $52 \%$ in hemipelagic sediments. The average abundances of GDGT-1 (VIII) and GDGT-2 (IX) were much lower, i.e. 7.3 and $7.6 \%$ for hemipelagic sediments, and 8.1 and $9.5 \%$ for mud breccia.

At every site GDGT-based ratios (GDGT-0/crenarchaeol and GDGT-2/crenarchaeol) revealed substantial variations with depth, mainly matching with the boundary between hemipelagic sediments and mud breccia intervals (Table 2). In mud breccia from Perejil (crater and flank) and Kalinin MV, both GDGT-0/crenarchaeol and GDGT-2/crenarchaeol ratios were enhanced. In contrast, these ratios were different for mud breccia from Schneider's Heart MV, the latter being similar to that at Perejil whereas the former was even lower than that for hemipelagic sediments, respectively (Table 2). The Methane Index (MI) defined by Zhang et al. (2011) was used to trace the presence of methanotrophic archaea. The MI ranged from 0.10, as the minimum value reported at Schneider's Heart mud breccia to a maximum of 0.45 at the mud breccia interval from Perejil MV crater (Table 2). On average, MI ranged from $0.22-0.33$ at the hemipelagic sedimentary drapes, while at mud breccia intervals the MI varied between 0.11 and 0.49 , in average (Table 2).

Low amounts of branched GDGTs (i.e. $<5 \%$ of total GDGTs) are present at all studied sites. In comparison with hemipelagic sediments, mud breccia intervals showed slightly higher amount of branched GDGTs (Fig. 6).

\subsection{Methane and sulfate}

Methane concentrations for gravity cores taken at the centre of Kalinin and Schneider's Heart MVs were low, 0.21 and $0.17 \mu \mathrm{M}$ wet sed, respectively. The methane concentration for the gravity core taken at Perejil crater increased in the lower part; the highest concentration being $231 \mu \mathrm{M}$ wet sed (Fig. 5). The concentration of pore-water sulfate remained at seawater level for Kalinin and Schneider's Heart MVs (unpublished results), whereas it had a significant decrease in the lower part of the sediments recovered for Perejil crater (Fig. 5).

\section{Discussion}

Within MV deposits, mud breccia rock clasts, matrix, fluid, and gas may not all be co-genetic (e.g. Stadnitskaia et al., 2008). In this regard, lipid biomarker distributions may provide key information on the potential source strata that feed mud volcanism, on the sedimentary sequence pierced by mud/fluids during eruptive episodes, and on the origin of the gas fraction within the extruded material.

\subsection{Source of organic matter in mud breccia and hemipelagic sediments}

Lipid biomarkers have been demonstrated to be useful geochemical proxies to characterize the organic geochemical signature of sediments from different facies e.g. mud volcanic deposits and hemipelagic sediments. In addition, this capacity enables us also to record the source of organic matter in mud breccia (Stadnitskaia et al., 2007, 2008).

Eglinton and Hamilton (1967) determined that terrestrial organic matter is typically characterized by relatively high CPI values (4-10) of the long-chain $n$ alkanes, derived from higher plant waxes. Meanwhile, the short-chain $n$ alkane distributions and low CPI values (close to 1) were reported to be typical for petroleum-derived compounds (Bray and Evans, 1961; Eglinton and Hamilton, 1963; Peters et al., 2005). We assume these two cases to be end-members with different lipid biomarker signatures that may be useful to determine different sources for the organic matter present in sediments and mud breccias. We applied this interpretation of $n$ alkane distribution patterns to the mud breccia matrices from Perejil, Kalinin and Schneider's Heart MVs. Intermediate CPI (2.02.9) and ACL (27.4-29.4) values (Fig. 3, Table 2) suggest a mixed origin of the organic matter contained in the mud breccia.

For all MVs, the CPI and ACL values in the hemipelagic sediments are slightly higher than in the mud breccia intervals. This indicates that the contribution from higher plants relative to petroleum-derived compounds is more predominant in hemipelagic sediments that it is in mud breccia. However, mixed signatures with more petroleum-derived content have been also found in the hemipelagic sediments, especially near the boundary between hemipelagic and mud breccia intervals. This particular finding is interpreted as a result of significant sediment reworking at these boundaries, which may be due to local blends caused by physical (i.e. sediment mobilization) and/or biological processes (i.e. intensive bioturbation). These processes may not only lead to the geochemical exchange between contiguous sedimentary facies but also favour the mixture of microfaunas encountered in these facies (Gennari et al., 2013). Consequently, we conclude that such processes may obscure the true location of the boundary between hemipelagic sediments and mud breccia in our studied cores. This is particularly evident in the lowermost mud flow of the Perejil flank core (RL08GC) where 

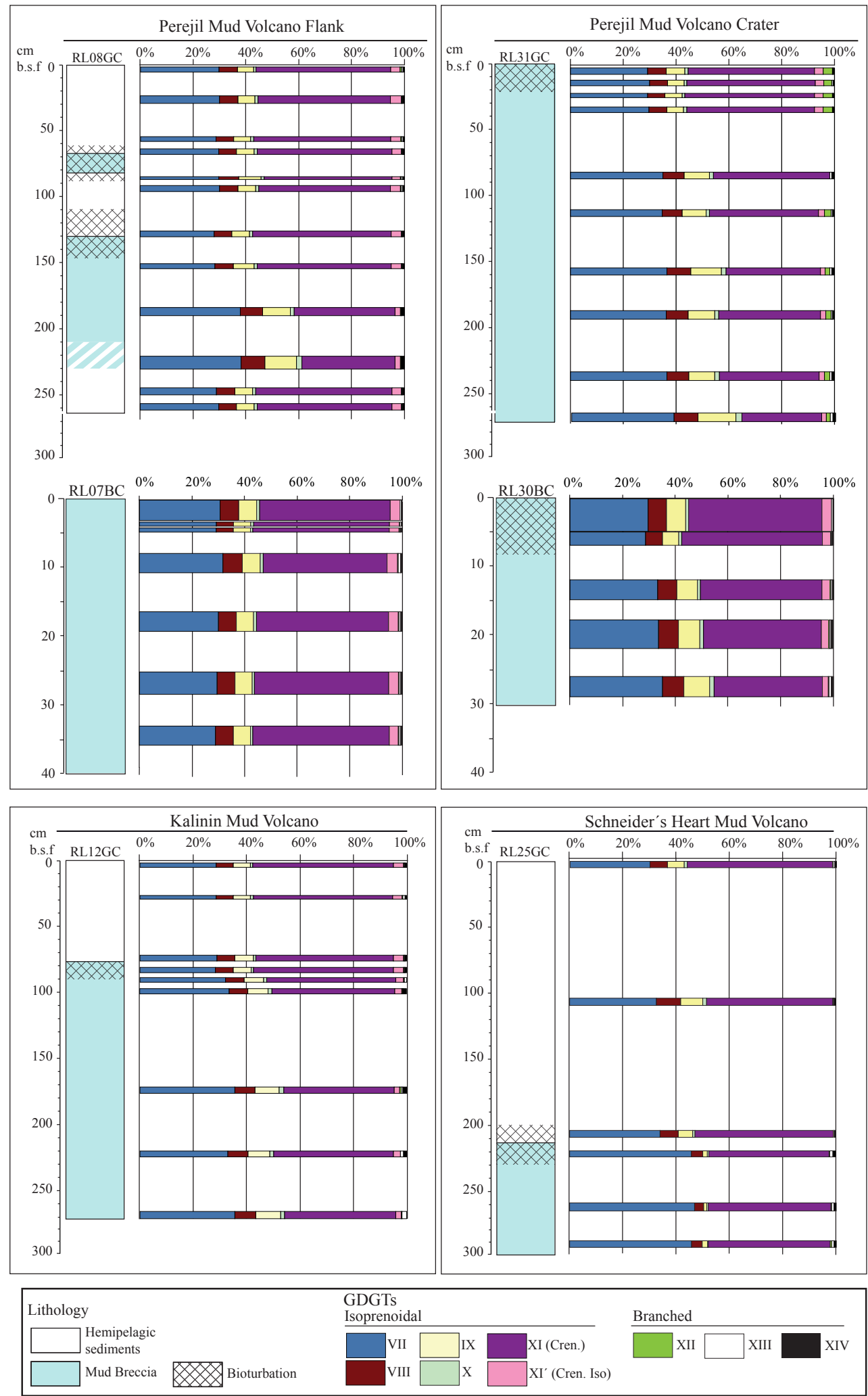

Figure 6. Fractional abundance (\%) of isoprenoidal and branched GDGTs for Perejil MV crater and flank and Kalinin and Schneider's Heart MVs. For GDGTs structures see Supplement. 
Table 3. Pentacyclic triterpenoids identified in Perejil MV crater and flank, Kalinin and Schneider's Heart MVs.

\begin{tabular}{|c|c|c|}
\hline Peak number & Compound name & Carbon number \\
\hline 1 & $17 \alpha(\mathrm{H})$-trisnorhopane & $\mathrm{C} 27$ \\
\hline 2 & $17 \beta(\mathrm{H})$-trisnorhopane & $\mathrm{C} 28$ \\
\hline 3 & $17 \alpha$-bisnormoretane & $\mathrm{C} 28$ \\
\hline 4 & $17 \alpha 21 \beta(\mathrm{H})-30$-norhopane & $\mathrm{C} 29$ \\
\hline 5 & $17 \beta 21 \alpha(\mathrm{H})$-30-norhopane & $\mathrm{C} 29$ \\
\hline 6 & $17 \alpha 21 \beta(\mathrm{H})$-hopane & $\mathrm{C} 30$ \\
\hline 7 & Isohop-13(18)-ene & $\mathrm{C} 30$ \\
\hline 8 & $17 \beta 21 \alpha(\mathrm{H})$-hopane (moretane) & $\mathrm{C} 30$ \\
\hline 9 & Diplopterol $(17 \beta 21 \beta(\mathrm{H})$-hopan-22-ol) & $\mathrm{C} 30$ \\
\hline 10 & $17 \alpha 21 \beta(\mathrm{H})$-homohopane $22 \mathrm{~S}$ & $\mathrm{C} 31$ \\
\hline 11 & $17 \alpha 21 \beta(\mathrm{H})$-homohopane $22 \mathrm{R}$ & $\mathrm{C} 31$ \\
\hline 12 & Diploptene (hop-22(29)-ene) & $\mathrm{C} 30$ \\
\hline 13 & $17 \alpha 21 \beta(\mathrm{H})$-bishomohopane $22 \mathrm{R}$ & $\mathrm{C} 32$ \\
\hline 14 & $17 \alpha 21 \beta(\mathrm{H})$-bishomohopane $22 \mathrm{R}$ & $\mathrm{C} 32$ \\
\hline 15 & $17 \beta 21 \beta(\mathrm{H})$-homohopane & $\mathrm{C} 31$ \\
\hline 16 & $17 \alpha 21 \beta(\mathrm{H})$-trishomohopane & $\mathrm{C} 33$ \\
\hline 17 & 20,32-cyclo- $17 \alpha$-bishomohopane-20,22,32-triene & $\mathrm{C} 32$ \\
\hline
\end{tabular}

all biomarker data suggest that the actual lower boundary is at $\sim 230 \mathrm{~cm}$ rather than at the visually detected boundary at $209 \mathrm{~cm}$ depth (Fig. 3a). In the following discussions we will, therefore, tentatively adopt this lower mud breccia boundary to be at $230 \mathrm{~cm}$ (Fig. 3a).

\subsection{Maturity of the organic matter}

The suite of lipid biomarkers, and in particular hopanes, found in sediments can be used to assess the degree of thermal maturation of the organic matter. The suite of hopanes found in the mud breccia matrices and especially the $22 \mathrm{~S} /(22 \mathrm{~S}+22 \mathrm{R})$ ratios for $\mathrm{C}_{31}$ and for $\mathrm{C}_{32}$ homohopane have a comparable distribution for all studied cores (Table 2). The average values for these two ratios are $0.49 \pm 0.06$ and $0.49 \pm 0.02$, respectively. These values are relatively close to the thermodynamic equilibrium value (ca. 0.6; Seifert and Moldovan, 1980; van Duin et al., 1997), indicating that at least part of the organic matter present in the mud breccia matrices has moderate to high degree of thermal maturation. However, the occurrence of small amounts of $17 \beta, 21 \beta(\mathrm{H})$ homohopane (Fig. 4, Table 3) indicates the presence of immature organic matter also. The coincidence of these two groups of rather different thermal maturity must indicate the presence of two different sources of organic matter. The CPI values for $n$ alkanes confirm this hypothesis, having values that imply moderately mature organic matter or a contribution of petroleum-derived compounds (Fig. 3, Table 2). However, the abundance of $n$ alkanes in the range of $\mathrm{C}_{29}$ $\mathrm{C}_{31}$ indicates also the presence of immature organic matter (Fig. 3, Table 2) (Bray and Evans, 1961; Eglinton and Hamilton, 1963; Peters et al., 2005). The thermal maturation degree that we found for hemipelagic sediment $(22 \mathrm{~S} /(22 \mathrm{~S}+22 \mathrm{R}) \mathrm{ra}-$ tios for $\mathrm{C}_{31}$ and for $\mathrm{C}_{32}$ homohopanes) ranges between $0.41-$
0.44 and $0.38-0.49$, respectively. This ratio is also much higher than commonly found for pelagic sediments, and suggests that part of the hopanes present in these sediments must come from a deeper source. This is in accordance with the interpretation that substantial mixing has occurred between hemipelagic and mud breccia sediments.

\subsection{Probable source strata}

The relatively high maturity degree that we report in mud breccia matrices from Perejil, Kalinin and Schneider's Heart MVs (Table 2) are in good agreement with the level of maturity found in other studies (Poludetkina and Kozlova, 2003, 2004; Poludetkina et al., 2008). In the same line, our maturity estimation for the mud breccia matrices from the three studied MVs are also in accordance with the previously reported data by Blinova et al. (2011), who found in Carmen MV a mixture of thermogenic and biogenic gases containing geochemical signatures typical of hydrocarbon generated during early stages of catagenesis. Therefore, all these suppositions support our hypothesis that part of the lipid biomarkers hosted in the mud breccia matrices of Perejil, Kalinin and Schneider's Heart MVs must originate from thermally matured organic matter at depth, i.e. in the lowermost Unit VI of the infill basin (Early to Middle Miocene in age), indicating the potential occurrence of primary cracking processes able to generate some thermogenic hydrocarbons (including methane).

This assumption is supported by the presence of thick overpressured sedimentary units forming the Mud Diapir Province that extend beneath the MVs edifices (Fig. 1, Comas et al., 2010 and references therein). As demonstrated by reflection seismic data, feeding conducts from mud volcano edifices are frequently rooted on pierced mud diapirs 
Table 4. Depth distributions of concentration of acyclic archaeal isoprenoids diagnostic for methanotrophic archaea and specific methanogen biomarkers such as diploptene and diplopterol for Perejil crater and flank, Kalinin, and Schneider's Heart MVs.

\begin{tabular}{|c|c|c|c|c|c|c|c|c|}
\hline Lithology & $\begin{array}{l}\text { intervals } \\
\text { (cm b.s.f.) }\end{array}$ & $\mathrm{Cr} /(\mathrm{Cr}+\mathrm{Ph})$ & $\begin{array}{c}\text { PMI } \\
\left(\mu \mathrm{g} \mathrm{g}^{-1}\right)\end{array}$ & $\begin{array}{l}\text { Archaeol } \\
\left(\mu \mathrm{g} \mathrm{g}^{-1}\right)\end{array}$ & $\begin{array}{c}\text { Hydroxyarchaeol } \\
\left(\mu \mathrm{g} \mathrm{g}^{-1}\right)\end{array}$ & $\begin{array}{l}\text { Diplopterol } \\
\left(\mu \mathrm{g} \mathrm{g}^{-1}\right)\end{array}$ & $\begin{array}{l}\text { Diploptene } \\
\left(\mu g^{-1}\right)\end{array}$ & $\begin{array}{l}\text { Non-isopren. } \\
\text { DGD }\left(\mu \mathrm{gg}^{-1}\right)\end{array}$ \\
\hline \multicolumn{9}{|c|}{ Perejil Mud Volcano RL07BC } \\
\hline \multirow[t]{7}{*}{ Mud Breccia } & $0-3$ & 0.71 & nd & 0.72 & nd & 2.67 & nd & nd \\
\hline & $3-4$ & 0.56 & nd & nd & nd & 1.13 & nd & nd \\
\hline & $4-5$ & 0.29 & nd & 0.71 & nd & 0.85 & nd & nd \\
\hline & $8-11$ & 0.65 & nd & 4.44 & 43.08 & 15.68 & nd & nd \\
\hline & $16.5-19.5$ & 0.56 & 2.37 & nd & nd & 1.48 & nd & nd \\
\hline & $25-28.5$ & 0.51 & 0.44 & 0.34 & 3.13 & 0.69 & nd & nd \\
\hline & $33-36$ & 0.49 & 0.70 & 2.54 & 20.02 & 2.34 & nd & nd \\
\hline \multicolumn{9}{|c|}{ Perejil Mud Volcano RL08GC } \\
\hline \multirow[t]{3}{*}{ Hem. Sed. } & $1-4$ & 0.52 & nd & nd & nd & 3.89 & 0.56 & nd \\
\hline & $25-30$ & 0.30 & nd & nd & nd & nd & 0.40 & nd \\
\hline & $55-58$ & 0.35 & nd & nd & nd & nd & 0.14 & nd \\
\hline Mud Breccia & $64-68$ & 0.40 & nd & nd & nd & 0.90 & 1.11 & nd \\
\hline \multirow[t]{2}{*}{ Hem. Sed. } & $86-88.5$ & 0.48 & nd & nd & nd & nd & 1.53 & nd \\
\hline & $91-94$ & nd & nd & nd & nd & nd & 0.21 & nd \\
\hline \multirow[t]{3}{*}{ Mud Breccia } & $137.5-140$ & 0.36 & nd & nd & nd & nd & 0.23 & nd \\
\hline & $151-154$ & 0.19 & nd & nd & nd & 2.26 & 0.71 & nd \\
\hline & $185.5-190$ & 0.36 & nd & nd & nd & nd & 1.34 & nd \\
\hline \multirow[t]{3}{*}{ Hem. Sed. } & $221-231$ & 0.39 & nd & nd & nd & 0.07 & 0.90 & nd \\
\hline & $246-250$ & nd & nd & nd & nd & nd & nd & nd \\
\hline & $257-261$ & nd & nd & nd & nd & nd & nd & nd \\
\hline \multicolumn{9}{|c|}{ Perejil Mud Volcano RL30BC } \\
\hline \multirow[t]{5}{*}{ Mud Breccia } & $0-5$ & 0.40 & nd & 0.32 & 9.25 & 2.02 & nd & nd \\
\hline & $5-7$ & 0.43 & nd & 0.24 & 6.16 & 0.71 & nd & nd \\
\hline & $12-15$ & 0.61 & 0.06 & 0.16 & nd & 0.25 & nd & nd \\
\hline & $18-22$ & 0.59 & nd & nd & 17.29 & 1.02 & nd & nd \\
\hline & $26-29$ & 0.47 & nd & 1.26 & nd & 3.60 & nd & nd \\
\hline \multicolumn{9}{|c|}{ Perejil Mud Volcano RL31GC } \\
\hline \multirow[t]{10}{*}{ Mud Breccia } & $5-8$ & 0.55 & nd & nd & 2.62 & 2.91 & 1.02 & nd \\
\hline & $12-16$ & 0.70 & nd & nd & nd & 1.24 & 0.63 & nd \\
\hline & $22-25$ & 0.63 & nd & nd & 5.50 & 2.09 & 0.44 & nd \\
\hline & $32-36$ & 0.52 & nd & nd & 0.53 & 0.29 & 0.98 & nd \\
\hline & $83-86$ & 0.81 & nd & nd & 1.29 & 0.16 & 1.11 & nd \\
\hline & $111-114$ & 0.76 & nd & 0.04 & 0.68 & 0.07 & 1.04 & nd \\
\hline & $155-159$ & 0.40 & nd & nd & nd & 0.26 & 1.31 & nd \\
\hline & $188-193$ & 0.45 & nd & nd & nd & 0.08 & 1.02 & nd \\
\hline & $234-239$ & 0.43 & nd & nd & nd & 0.08 & 1.34 & nd \\
\hline & $266-271$ & 0.41 & nd & 0.12 & 2.66 & 0.22 & 1.32 & nd \\
\hline \multicolumn{9}{|c|}{ Kalinin Mud Volcano RL12GC } \\
\hline \multirow[t]{3}{*}{ Hem. Sed. } & $2-4$ & nd & nd & nd & nd & nd & nd & nd \\
\hline & $25-29$ & nd & nd & nd & nd & 11.31 & nd & nd \\
\hline & $72-76$ & 0.41 & nd & nd & nd & 2.45 & nd & nd \\
\hline \multirow[t]{6}{*}{ Mud Breccia } & $81-83.5$ & 0.40 & nd & nd & nd & 4.73 & 0.71 & nd \\
\hline & $89.5-91.5$ & 0.48 & 0.24 & 1.41 & nd & 4.31 & 1.09 & nd \\
\hline & $96.5-100.5$ & 0.46 & 0.67 & nd & nd & 12.49 & 0.85 & nd \\
\hline & $172-176$ & 0.38 & nd & 2.48 & nd & 5.93 & 1.58 & nd \\
\hline & $230-233.5$ & 0.44 & nd & 0.56 & nd & 2.16 & 1.50 & nd \\
\hline & $268.5-272$ & 0.36 & nd & 3.40 & nd & 4.89 & 1.49 & nd \\
\hline \multicolumn{9}{|c|}{ Schneider's Heart Mud Volcano RL25GC } \\
\hline \multirow[t]{3}{*}{ Hem. Sed. } & $0-5$ & 0.30 & 0.15 & nd & nd & nd & nd & nd \\
\hline & $105-110$ & nd & nd & nd & nd & nd & nd & nd \\
\hline & $205-210$ & 0.30 & nd & nd & nd & nd & 0.58 & nd \\
\hline \multirow[t]{3}{*}{ Mud Breccia } & $220-225$ & 0.33 & nd & nd & nd & nd & 0.41 & 0.63 \\
\hline & $260-265$ & 0.42 & nd & nd & nd & nd & 0.23 & 0.36 \\
\hline & $290-295$ & 0.24 & nd & nd & nd & nd & 0.55 & 0.93 \\
\hline
\end{tabular}


(i.e. Talukder et al., 2003; Comas et al., 2012; Soto et al., 2010). Overpressured units forming the mud diapirs and subsequently lending to the mud volcanism correspond to the basal Unit VI and Unit V, Early to Middle Miocene (Fig. 2) (i.e. Comas et al., 1999, 2012; Talukder et al., 2003; Soto et al., 2003, 2010). Tectonic processes that have occurred since the Middle Miocene (to nowadays) have been reported to cause both the mud-diapirism and the subsequent mud volcanism that reaches the actual sea floor (see Geological Background above). Hence, they all identify the overpressured deeper strata laid down in the West Alboran Basin (Unit VI and the lower part of Unit V, Early to Middle Miocene in age, Fig. 2) as the most probable source strata of the mud-volcanism products.

For the West Alboran Basin, temperatures of $\sim 100$ $150^{\circ} \mathrm{C}$ were suggested to be reached at $4-6 \mathrm{~km}$ sedimentary depths, under a geothermal gradient of $25^{\circ} \mathrm{C} \mathrm{km}^{-1}$ (Torné et al., 2000). According to these data and regarding the sedimentary lithology of the lowermost unit of the basin (undercompacted olistostromes embedded in a shale-rich matrix) (Fig. 2), the beginning of the "oil window" may be located at this depth, matching with the lower-to middle Miocene strata (Unit VI). This is in good agreement with our lipid biomarkers data, and is supported by the location at depth and sedimentary lithologies of units VI and V (Fig. 2) as indicated by seismic data (i.e. Comas et al., 2012, Soto et al., 2010). Furthermore, this assumption is consistent with geochemical studies carried out on pore water and gases for other Alboran MVs, which reveals a thermogenic origin for the volcanic fluids (Blinova et al., 2011).

\subsection{Recent microbial activity}

At the Alboran MVs, GDGTs in hemipelagic sediments reflect the predominant marine pelagic thaumarchaeotal signature (Fig. 6; Schouten et al., 2012 and references therein). In contrast, mud breccia intervals show differences in GDGT distribution between individual MVs. Schneider's Heart MV has a predominance of GDGT-0 and crenarchaeol, clearly revealing the influence of marine pelagic thaumarchaeotal and, consequently, inactive anaerobic oxidation of methane (AOM) at this site. This is also confirmed by the absence of irregular isoprenoids (crocetane and PMI) and isoprenoidal dialkyl glycerol diethers (archaeol and hydroxyarchaeol) (Table 4). This is in line with the observed methane content at Schneider's Heart relative to Perejil MV, being respectively $<0.18 \mu \mathrm{M}$, relative to $\sim 230 \mu \mathrm{M}$ wet sediment. At Kalinin MV and more especially at Perejil MV, the GDGT distribution and in particular the GDGT-based ratios (MI > 0.4; elevated GDGT-2/Crenarchaeol and GDGT-0/Crenarchaeol ratios; Table 2), document the occurrence of AOM performed by anaerobic methanotrophic archaea (ANME). However, some differences in GDGT-based ratios and also in archaeal lipid biomarkers (mainly in crocetane contents; Table 2) indicate a lower rate of anaerobic oxidation of methane (AOM) at Kalinin MV compared with Perejil MV (Table 2). In Perejil MV crater, the finding of authigenic pyrite in the mud breccia suggests that recent methane fluxes and concordant sulfate-reducing processes occur at this site. This concurs with the observed profiles for methane and sulfate for Perejil MV crater (Fig. 5). Furthermore, microbial communities that are involved in AOM biosynthesize specific lipid biomarkers that are strongly depleted in $\delta^{13} \mathrm{C}$ (Hinrichs et al., 1999; Pancost et al., 2000). Indeed, in Perejil MV crater, at $\sim 100 \mathrm{~cm}$ depth there is evidence for strongly depleted crocetane (Fig. 5), confirming the consumption of hydrocarbons, mainly methane, by archaea of ANME-2 cluster for this MV (Niemann and Elvert, 2008). Moreover, at Perejil MV, the distribution of GDGTs also suggests that archaea belonging to the ANME -1 group also perform AOM in these mud breccia (Fig. 6, Table 4) (Blumenberg et al., 2004, Stadnitskaia et al., 2005).

\subsection{MV dynamics}

The lipid biomarker composition provides information about the dynamic processes at the MVs, such as discrete events of mud-flow expulsion. Furthermore, the presence or absence of hemipelagic intervals intercalated or draping mud breccia episodes helps to determine volcanic pulses.

At the Perejil MV crater, the absence of hemipelagic sediments and the observed gas bubbling noticed during the core recovery, indicate that our sampled site correspond to a relatively very recent mud flow eruption. Where no clear lithological boundaries can be seen, some changes in the distributions of lipid biomarkers (Figs. 3, 6, Table 2) can be used to make a more precise lithology distinction between "real" hemipelagic and mud breccia intervals.

In accordance with our biomarker results, cases of boundary transitions between the two lithologies occur in Kalinin MV (core RL12GC) at $\sim 80 \mathrm{~cm}$ and in Schneider's Heart MVs (core RL25GC) at $\sim 220 \mathrm{~cm}$ depth (Fig. 3b). At Perejil MV crater (core RL31GC), the more subtle but evident decrease in branched GDGTs, together with the variation in other lipid biomarkers such as CPI values and $n$ alkane distributions (Fig. 3a), are noted at $\sim 110$ and $\sim 190 \mathrm{~cm}$, which may represent (brief) interruptions of mud expulsion, whereas the change above $40 \mathrm{~cm}$ may reflect the ongoing bioturbation since the last eruptive event. In accordance with this interpretation, three consecutive mud expulsion events are detected at Perejil MV crater, i.e. below 190, 110-190 cm, and above $110 \mathrm{~cm}$. Compared to Perejil MV, Kalinin and Schneider's Heart MVs are characterized by relatively thick hemipelagic draping, indicative of relatively old mud breccia flows (Fig. 3b). This fact, together with the absence of chemosynthetic macrofauna, suggests that both MVs are currently inactive, at least at our sampling locations.

The observed reduced relative abundance of branched GDGTs and the interpretations given are consistent with the occurrence of some oxidative mixing between pelagic and 
mud breccia facies. As indicated above, mud fluid ejection and biological processes such as bioturbation may have influenced such mixing (Fig. 3, Table 2) at some boundaries between hemipelagic/ mud breccia intervals. Studies on the microfauna contained in mud breccia from some other Alboran MVs revealed significant mixture of foraminifera species from diverse ages, thus proving that mixing between hemipelagic sediments and mud breccia facies exists (Gennari et al., 2013). Consequently, and in accordance with our findings, we propose that lipid biomarkers, can be used as reliable proxy to discriminate between sedimentary and MVderived facies within mud volcano edifices.

The presence of AOM-related biomarkers, although at relatively low levels, is evident at the three studied MVs of the Alboran Sea (Table 4). This indicates that at least brief periods of methane emission must have occurred but that continuous fluxes of hydrocarbon-rich fluids at these MVs are unlikely. This interpretation is consistent with hydrocarbon gas data (Fig. 5) determined here and those reported by Blinova et al. (2011). Although our methane content for Perejil MV is much higher than those reported by Blinova et al. (2011) $(230 \mu \mathrm{M}$ sed vs. $\sim 2 \mu \mathrm{M}$ sed), compared to actively seeping MVs, the methane concentrations observed at Perejil are rather low $(230 \mu \mathrm{M}$ sed), compared to $>1000 \mu \mathrm{M}$ sed for known active MV seepages (e.g. Mastalerz et al., 2007).

Differences exist in the methane concentrations at Perejil MV that are reported here and those reported by Blinova et al. (2011) from neighbouring sampling sites, which can be explained due to the dissimilar hydrocarbon contents of seeps via contiguous conduits within the volcano. Alternatively, such differences may result from changes in the composition and activity of seepages through time. However, further analyses and in situ MV-monitoring are needed to clearly discriminate between both options.

Furthermore, the presence of AOM-related biomarkers confirms that AOM activity at Perejil MV is relatively recent (Fig. 5, Table 4). Also the absence of a hemipelagic drape supports that core RL31CG, recovered from the crater of the Perejil MV, sampled a recent mud-flow event that may have occurred only some years ago. On the basis of all these findings we consider Perejil MV the currently most active MV at the northern margin of the West Alboran Basin.

\section{Conclusions}

Mud breccias sampled in three studied MVs from the northern West Alboran Basin present similar suites of lipid biomarker compositions and maturity properties of organic matter indicating a common source for the extruded mud breccia at the studied volcanic structures.

Our lipid biomarker results, in agreement with previous geophysical and stratigraphic data, confirm that the source strata of the organic matter in mud breccia belong to overpressured deep units occurring at depth in the West Albo- ran Basin (Unit VI and Unit V, Early to Middle Miocene in age). The moderate mature-immature characteristics of the organic matter present in mud breccias corroborate a deep source for the upward fluids, at least at Perejil and Kalinin MVs.

Significant mixing may occur between hemipelagic sediment and mud-breccia facies at the interval boundaries, resulting in the significant variation of some lipid biomarkers, such as $n$ alkanes. Using this variability found in the lipid biomarker distributions, we suggest the occurrence of a very recent mud-flow eruption at Perejil MV and at least another two previous volcanic events.

The presence of specific AOM-related biomarkers together with direct evidence of recent activity (e.g. chemosynthetic fauna, gas bubbling, enhanced levels of methane and reduced level of sulfate), proves the occurrence of actual methane seepage at Perejil MV.

At Perejil MV, the presence of these AOM-related biomarkers indicates that active AOM is occurring at this structure. Additionally, the specific AOM-related biomarkers found at this MV have proved the co-occurrence of ANME-2 over ANME-1 group. In contrast, the low occurrence or absence of specific lipid biomarkers related to methanotrophic archaea in the mud breccia at Kalinin and Schneider's Heart MVs suggests that very low or no AOM occurs at these sites, respectively.

\section{The Supplement related to this article is available online at doi:10.5194/bg-11-3187-2014-supplement.}

Acknowledgements. The authors gratefully acknowledge the RISTRETTO e LUNGO M83/3 Shipboard Party, technicians as well as Captain M. Schneider and crew of R/V Meteor for support and collaboration during the cruise. D. Gallego-Torres is acknowledged for on-board methane analyses, and C. Tessarolo for construction of maps based on MultiBeam observations. Special thanks go to S. Schouten and all the staff from the Marine Organic Biogeochemistry Department from NIOZ. This study was supported by Project CTM2009-07715, CGL2011-1441 and CGL2012-32659 (MINECO, Spain), by the VENI grant from the Netherlands Organization for Scientific Research (NWO) and the Royal Netherland Institute for Sea Research (NIOZ via ZKOprogramme) (Texel, The Netherlands). C. F. López-Rodríguez was funded by a JAE-PhD fellowship from the CSIC (Spain).

Edited by: S. Pantoja

\section{References}

Akhmanov, G. G.: Lithology of mud breccia clasts from the Mediterranean Ridge, Mar. Geol., 132, 151-164, 1996.

Akhmanov, G. G. and Woodside, J. M.: Mud Volcanic Samples in the context of the Mediterranean Ridge Mud Diapiric Belt, in: 
Proceedings of the Ocean Drilling Programme: Scientific Results, College Station, Texas, 160, 597-605, 1998.

Bian, L., Hinrichs, K.-U., Xie, T., Brassell, S. C., Iversen, N., Fossing, H., Jørgensen, B. B., and Hayes, J. M.: Algal and archaeal polyisoprenoids in a recent marine sediment: molecular isotopic evidence for anaerobic oxidation of methane, Geochem. Geophy. Geosy, 2, 1525-2027, 2001.

Blinova, V. N., Comas, M. C., Ivanov, M. K., Poludetkina, E., and Matveeva, T. V.: Active mud volcanism in the West Alboran Basin: Geochemical evidence of hydrocarbon seepage, Mar. Petrol. Geol., 28, 1483-1504, 2011.

Blumenberg, M., Seifert, R., Reichart, G. J., Pape, T., and Michaelis, W.: Membrane lipid patterns typify distinct anaerobic methanotrophic consortia, P. Natl. Acad. Sci., 101, 1111111116, 2004.

Boetius, A., Ravenschlag, K., Schubert, C. J., Rickert, D., Widdel, F., Gieseke, A., Amann, R., Jørgensen, B. B., Witte, U., and Pfannkuche, O.: A marine microbial consortium apparently mediating anaerobic oxidation of methane, Lett. Nat., 407, 623-626, 2000.

Bray, E. E. and Evans, E. D.: Distributions of $n$-paraffins as a clue to recognition of source beds, Geochim. Cosmochim. Ac., 22, 2-15, 1961.

Cita, M. B., Ryan, W. B. F., and Paggi, L.: Prometheus mud breccia. An example of shale diapirism in the Western Mediterranean Ridge, Ann. Geo. Pa. Héllén., 30, 543-569, 1981.

Comas, M. C., Zahn, R., and Klaus, A.: Proceedings of the Ocean Drilling Program, Science Results 161, college Station, TX, USA, 1996.

Comas, M. C., Platt, J. P., Soto, J. I., and Watts, A. B.: The origin and tectonic history of the Alboran Basin: evidence from Leg 161, Proceedings of the Ocean Drilling Program, Sci. Res., college Station, TX, USA, 161, 555-580, 1999.

Comas, M. C., Pinheiro, L. M., Ivanov, M. K., and TTR-17 Scientific Party: The Alboran Sea Leg-1: Look into mud volcanoes, carbonate mounds and climate changes, IOC Technical Series, 94, 8-64, 2010.

Comas, M. C., Suades, E., and Crespo-Blanc, A.: From mud diapirs to mud volcanoes: Shale tectonics within the structural evolution of the Alboran Sea basin, Geotemas, 13, 138-141, 2012.

Corselli, C. and Basso, D.: First evidence of benthic communities based on chemosynthesis on the Napoli mud volcano (Eastern Mediterranean), Mar. Geol., 132, 227-239, 1996.

Dewey, J. F., Helman, M. L., Turco, E., Hutton, D. W. H., and Knott, S. D.: Kinematics of the western Mediterranean, in: Alpine Tectonics. Geol. Soc. Lon. Spec. Publ., edited by: Coward, M. P., Dietrich, D., and Park, R. G., 45, 265-28, 1989.

Díaz-Merino, C., Comas, M. C., and Martínez del Olmo, W.: Secuencias de depósito neógenas del margen noroeste del Mar de Alborán, Cuenca de Málaga, Geotemas, 5, 61-65, 2003.

Dimitrov, L. I.: Mud volcanoes - the most important pathway for degassing deeply buried sediments, Earth-Sci. Rev., 59, 49-76, 2002.

Eglinton, G. and Hamilton, R. J.: The distribution of $n$-alkanes, in: Chemical Plant Taxonomy, Academic Press, 187-217, 1963.

Eglinton, G. and Hamilton, R. J.: Leaf epicuticular waxes, Science, 156, 1322-1335, 1967.

Elvert, M., Suess, E., Greinert, J., and Whiticar, M. J.: Archaea mediating anaerobic methane oxidation in deep-sea sediments at cold seeps of the eastern Aleutian subduction zone, Org. Geochem., 31, 1175-1187, 2000.

Etiope, G., Feyzullayev, A., and Baciu, C. L.: Terrestrial methane seeps and mud volcanoes: A global perspective of gas origin, Mar. Petrol. Geol., 26, 333-344, 2009.

Gennari, G., Spezzaferri, S., Comas, M. C., Rüggerberg, A., LópezRodríguez, C., and Pinheiro, L. M.: Sedimentary sources of the mud-breccia and mud volcanic activity in the Western Alboran Basin, Mar. Geol., 339, 83-95, 2013.

Guliyev, I. S. and Feizullaev, A. A.: All about mud volcanoes, Nafta Press, Baku, 1997.

Hilario, A., Comas, M. C., Azevedo, L., Pinheiro, L., Ivanov, M. K., and Cunha, M. R.: First record of a vestimentifera (Polychaeta: Siboglinidae) from chemosynthetic habitats in the western Mediterranean Sea e biogeographical implications and future exploration. Deep Sea Res. I, 58, 200-207, 2011.

Hinrichs, K.-U., Hayes, J. M., Sylva, S. P., Brewer, P. G., and De Long, E. F.: Methane-consuming archaeabacteria in marine sediments, Nature, 398, 802-805, 1999.

Hinrichs, K-U., Pancost, R. D., Summons, R. E., Sprott, G. D., Sylva, S. P., Sinninghe Damsté, J. S., and Hayes, J. M.: Mass spectra of Sn-2-hydroxyarchaeol, a polar lipid biomarker for anaerobic methenotrophy, Geochem. Geophy. Geosy., 1, 15252027, 2000.

Hopmans, E. C., Schouten, S., Pancost, R. D., van der Meer, M. T. J., and Sinninghe Damsté, J. S.: Analysis of intact tetraether lipids in archaeal cell material and sediments by high performance liquid chromatography/atmospheric pressure chemical ionization mass spectrometry, Rapid Commun. Mass Sp., 14, 585-589, 2000.

Jurado, M. J. and Comas, M. C.: Well log interpretation and seismic character of the Cenozoic sequence in the Northern Alboran Sea, GeoMar. Lett., 12, 129-136, 1992.

Knittel, K. and Boetius, A.: Anaerobic Oxidation of Methane: Progress with an Unknown Process, Ann. Rev. Microbio., 63, 311-34, 2009.

Knittel, K., Lösekann, T., Boetius, A., Kort, R., and Amann, R.: Diversity and distribution of methanotrophic archaea at cold seeps, Appl. Environ. Microbiol., 71, 467-479, 2005

Kozlova, E., Ivanov, M. K., Baudin, F., Largeau, C., and Derenne, S.: Composition and maturity of organic matter in the rock clasts of mud volcanic breccia. North Atlantic and Labrador Sea Margin Architecture and Sedimentary Process, in: International Conference and Twelfth Post-Cruise Meeting of the TrainingTrough-Research programme, Copenhagen, Denmark, Intergovern. Oceanogr. Commiss. Workshop Report, 191, 24-25, 2004.

López-Rodríguez, C., de Lange, G. J., Martínez-Ruíz, F., and Comas, M.: Fluid venting and methane seep activity in Carmen MV, West Alboran Basin, in preparation, 2014.

Mastalerz V., de Lange G. J., Dahlmann A., and Feseker, T.: Active venting at the Isis mud volcano, offshore Egypt: Origin and migration of hydrocarbons, Chem. Geol., 246, 87-106, 2007.

Mastalerz, V., de Lange, G. J., and Dahlmann, A.: Differential aerobic and anaerobic oxidation of hydrocarbon gases discharged at mud volcanoes in the Nile deep-sea fan, Geochim. Cosmochim. Ac., 73, 3849-3863, 2009.

Milkov, A. V., Sassen, R., Apanasovich, T. V., and Dadashev, F.: Global gas flux from mud volcanoes: A significant source of fos- 
sil methane in the atmosphere and the ocean, Geophys. Res. Lett., 30, 1037, doi:10.1029/2002GL016358, 2003.

Niemann, H. and Elvert, M.: Diagnostic lipid biomarker and stable carbon isotope signatures of microbial communities mediating the anaerobic oxidation of methane with sulphate, Org. Geochem., 39, 1668-1677, 2008.

Olu, K., Sibuet, M., Harmegnies, F., Foucher, J. P., and FialaMédioni, A.: Spatial distribution of diverse cold seep communities living on various diapiric structures of the southern Barbados prism, Prog.Oceanogr., 38, 347-376, 1996.

Ovsyannikov, D. O., Sadekov, A., Yu, and Kozlova, E. V.: Rock fragments from mud volcanic deposits of the Gulf of Cadiz: an insight into the Eocene-Pliocene sedimentary succession of the basin. Mar. Geol., 195, 211-221, 2003

Pancost, R. D., Sinninghe Damsté, J. S., De Lint, S., Van der Maarel, M. J. E. C., Gottschal, J. C., and the Medinaut Shipboard Scientific Party: Biomarker evidence for widespread anaerobic methane oxidation in Mediterranean sediments by a consortium of methanogenic archaea and bacteria, Applied and Environ. Microbiol., 66, 1126-1132, 2000.

Pancost, R. D., Bouloubassi, I., Aloisi, G., Sinninghe Damsté, J. S., and the Medinaut Shipboard Scientific Party: Three series of non-isoprenoidal Dialkyl glycerol diethers in cold-seeps carbonate crusts, Org. Geochem., 32, 695-707, 2001.

Peters, E. K., Walters, C. C., and Moldovan, J. M.: The Biomarker Guide. 2nd Edn., Cambridge University Press, UK, 2005.

Poynter, J.: Molecular stratigraphy: The recognition of paleoclimate signals in organic geochemical data, $\mathrm{PhD}$ Thesis, University of Bristol, 324 pp., 1989.

Poludetkina, E. and Kozlova, E.: Geochemical Characteristics of Hydrocarbon Gases and Organic Matter from Mud Volcanic Deposits of the Alboran Sea, in: Geological and Biological Processes at Deep-sea European Margins and Oceanic Basins (TTR12 Post Cruise Meeting), Bologna, Italy, IOC Workshop Report No. 187, 5-7, 2003.

Poludetkina, E., Comas, M., Kozlova, E., and Ivanov, M.: Geochemical Preconditions of Oil-Gas-Bearing Capacity of the Alboran Basin. First MAPG International Conference and Exhibition, Marrakech, Morocco, 2008.

Reeburgh, W. S.: Methane consumption in Cariaco Trench waters and sediments, Earth Planet. Sc. Lett., 28, 337-344, 1976.

Reeburgh, W. S.: "Soft spots" in the global methane budget, in: Microbial growth on $\mathrm{C} 1$ compounds, edited by: Lidstrom, M. E. and Tabita, F. R., Kluwer Academic Publishers, 334-342, 1996.

Rodríguez-Fernández, J., Comas, M. C., Soría, J., Martín-Pérez, J. A., and Soto, J. I.: The sedimentary record of the Alboran Basin: An attempt at sedimentary sequence correlation and subsidence analysis, in: Proceedings ODP, Scientific Results, edited by: Zahn, R., Comas, M. C., and Klaus, A., College Station, TX (Ocean Drilling Program), 161, 69-76, 1999.

Sautkin, A., Talukder, A. R., Comas, M. C., Soto, J. I., and Alekseev, A.: Mud volcanoes in the Alboran Sea: evidence from micropaleontological and geophysical data, Mar. Geol., 195, 237261, 2003.

Schouten, S., Hopmans, E. C., and Sinninghe Damsté, J. S.: The organic geochemistry of glycerol dialkyl glycerol tetraether lipids: a review, Org. Geochem., 54, 19-61, 2012.

Seifert, W. K. and Moldovan, J. M.: The effect of thermal stress on source-rock quality as measured by hopane stereochemistry, in:
Phys. Chem. Earth, edietd by: Maxwell, J. R., Pergamon, Oxford, 229-237, 1980.

Sinninghe Damsté, J.S., Schouten, S., Hopmans, E. C., van Duin, A. C. T., and Geenevasen, J. A. J.: Crenarchaeol: the characteristic core glycerol dibiphytanyl glycerol tetraether membrane lipid of cosmopolitan pelagic crenarchaeota, J. Lipid. Res., 43, 16411651, 2002.

Soto, J. I., Comas, M. C., and de la Linde, J.: Espesor de sedimentos en la cuenca de Alborán mediante una conversión sísmica corregida, Geogaceta, 20, 382-385, 1996.

Soto, J. I., Comas, M. C., and Talukder, A.: Evolution of the mud diapirism in the Alboran Sea (Western Mediterranean), in: AAPG International Conference, Barcelona, Spain, 187, 1-6, 2003.

Soto, J. I., Fernandez-Ibanez, F., Talukder, A. R., and MartínezGarcía, P.: Miocene shale tectonics in the northern Alboran Sea (western Mediterranean), in: Shale tectonics: AAPG Memoir, edited by: Wood, L., 93, 119-144, 2010.

Stadnitskaia, A., Muyzer, T. G., Abbas, B., Coolen, M. J. L., Hopmans, E. C., Baas, M., van Weering, T. C. E., Ivanov, M. K., Poludetkina, E., and Sinninghe Damsté, J. S.: Biomarker and 16S rDNA evidence for anaerobic oxidation of methane and related carbonate precipitation in deep-sea mud volcanoes of the Sorokin Trough, Black Sea, Mar. Geol., 217, 67-96, 2005.

Stadnitskaia, A., Blinova, V., Ivanov, M. K., Baas, M., Hopmans, E., van Weering, T. C. E., and Sinninghe Damsté, J. S.: Lipid biomarkers in sediments of mud volcanoes from the Sorokin Trough, NE Black Sea: Probable source strata for the erupted material, Org. Geochem., 38, 67-83, 2007.

Stadnitskaia, A., Ivanov, M. K., and Sinninghe Damsté, J. S.: Application of lipid biomarkers to detect sources of organic matter in mud volcano deposits and post-eruptional methanotrophic processes in the Gulf of Cadiz, NE Atlantic, Mar. Geol., 255, 1-14, 2008.

Talukder, A. R., Comas, M. C., and Soto, J. I.: Pliocene to Recent mud diapirism and related mud volcanoes in the Alboran Sea (Western Mediterranean), Geol. Soc. Lon. Spec. Publ., 216, 443 459, 2003.

Talukder, M. A. R.: La Provincia Diapírica de lodo en la Cuenca Oeste del Mar de Alborán: Estructuras, Génesis y Evolución, PhD Thesis, Granada University, Granada, 251 pp., 2003.

Torné, M., Fernàndez, M., Comas, M. C., and Soto, J. I.: Lithospheric structure beneath the Alboran Basin: results from 3-D gravity modeling and tectonic relevance. J. Geohys. Res., 105, 3209-3228, 2000.

Van Duin, A. C. T., Sinninghe Damsté, J. S., Koopmans, M. P., Van de Graaf, B., and De Leeuw, J. W.: A kinetic calculation method of homohopanoid maturation: Applications in the reconstruction of burial histories of sedimentary basins, Geochim. Cosmochim. Ac., 61, 2409-2429, 1997.

Vanreusel, A., Andersen, A.C., Boetius, A., Connelly, D. P., Cunha, M. R., Decker, C., Hilário, A., Kormas, K. A., Maignien, L., Olu, K., Pachiadaki, M., Ritt, B., Rodrigues, C. F., Sarrazin, J., Tyler, P. A., Van Gaever, S., and Vanneste, H.: Biodiversity of cold seep ecosystems along the European margins, Oceanography, 22, 110-127, 2009.

Weijers, J. W. H., Schouten, S., Hopmans, E. C., Geenevasen, J. A. J., David, O. R. P., Coleman, J. M., Pancost, R. D., and Sinninghe Damsté, J. S.: Membrane lipids of mesophilic anaerobic bacteria 
thriving in peats have typical archaeal traits, Environ. Microbiol., 8, 648-657, 2006.

Weijers, J. W. H., Lim, K. L. H., Aquilina, A., Sinninghe Damsté, J. S., and Pancost, R.: Biogeochemical controls on glycerol dialkyl glycerol tetraether lipid distributions in sediments characterized by diffusive methane flux, Geochem. Geophy. Geosy., 12, 15252027, 2011.
Wheeler, A. J. and Stadnitskaia, A.: Benthic deep-sea carbonates: reefs and seeps, in: , Deep-Sea Sediments, Developments in Sedimentology, edited by: Hüneke, H. and Mulder, T., Elsevier, Amsterdam, 63, 397-455, 2011.

Zhang, Y. G., Zhang, C. L., Liu, X. L., Li, L., Hinrichs, K. U., and Noakes, J. E.: Methane Index: A tetraether archaeal lipid biomarker indicator for detecting the instability of marine gas hydrates, Earth Planet. Sc. Lett., 307, 525-534, 2011. 